NASA Technical Memorandum 86906 AIAA-85-0468

\title{
Icing Flight Research: Aerodynamic Effects of Ice and Ice Shape Documentation With Stereo Photography
}

Kevin L. Mikkelsen, Robert C. McKnight, and Richard J. Ranaudo

Lewis Research Center

Cleveland, Ohio

and

Porter J. Perkins, Jr.

Sverdrup Technology, Inc.

Middleburg Heights, Ohio

Prepared for the

Twenty-third Aerospace Sciences Meeting sponsored by the American Institute of Aeronautics and Astronautics Reno, Nevada, January 14-17, 1985

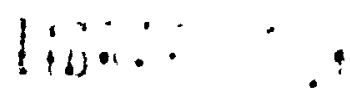

Mar $\geq C_{1}$. 


\section{ICING FLIGHT RESEARCH: AERODYNAMIC EFFECTS OF ICE AND ICE SHAPE DOCUMENTATION WITH STEREO PHOTOGRAPHY}

Kevin L. Mikkelsen, Robert C. MCKnight, and Richard J. Ranaudo National Aeronautics and Space Administration

Lewis Research Center

Cleveland, Ohio

and

Porter J. Perkins, Jr.

Sverdrup Technology, Inc.

Middleburg Heights, Ohio

Abstract

Aircraft icing flight research was performed in natural icing conditions with a typical twin engine commuter type aircraft. Development of a data base consisting of icing cloud parameter measurements, ice shapes, and aerodynamic measurements was begun. Results from five icing research flights are presented. During research icing encounters, icing cloud parameters such as temperature, liquid water content, and droplet size were measured. After the $1 \mathrm{cing}$ encounter, ice shapes were documented and aerodynamic measurements were taken. The ice accretion shape on tise wing was documented with a stereo photography system. The increase in wing section drag was measured with a wake survey probe. The overall alrcraft performance loss in terms of $11 \mathrm{ft}$ and drag coefficient changes was obtarned by taking steady level speed/ power measurements. Selective deicing of airframe components was performed to determine their contributions to the total drag increase. Engine out capability was analyzed for the iced aircraft. It was shown that the stereo photography system can be used to document ice shapes in flight and that the wake survey probe can measure increases in wing section drag caused by ice. On one flight, the wing section drag coefficient $\left(C_{d}\right)$ increased approximately 120 percent over the uniced baseline at an aircraft angle of attack of $6^{\circ}$. On another firght, the aircraft drag coefficient $\left(C_{0}\right)$ increased by 75 percent over the uniced baseline at an aircraft lift coefficient $\left(C_{L}\right)$ of 0.5 .

\section{Nomenclature}

$\mathrm{C}_{\mathrm{L}}$ aircraft lift coefficient

$C_{D} \quad$ aircraft drag coefficient

C) wing section iift coefficient

$C_{d} \quad$ wing section drag coefficient

KIAS indicated airspeed, kn

KTAS true airspeed, $k n$

LWC liquid water content, $\mathrm{g} / \mathrm{m}^{3}$

MED mean effective droplet diameter, $\mu \mathrm{m}$

MVD median volume droplet diameter, $\mu \mathrm{m}$

RMC rotating multicylinder

SHP shaft horsepower, hp

ss sooted slide droplet catcher
THP thrust horsepower, hp

a alrcraft angle of attack referenced to floor line, deg

of flap deflection, deg

\section{Introduction}

The NASA Lewis Research Center is conducting an aircraft icing research program. Flight testing is performed in natural icing conditions to support several major program elements. 1,2 Among these elements are flight experiments that provide ice accretion shape and attendant aerodynamic drag data for the purpose of validating the NASA Lewis Icing Research Tunnel and computer codes. ${ }^{3}$ As a part of this program $191 \mathrm{cing}$ research flights were flown during the $1983 / 1984$ season. Because the results of many flights were similar and in order to avoid repetition and to focus in on key observations and results, data from only five $1 \mathrm{cing}$ flights are described.

This paper presents results of NASA's 1cing flight research in the following areas: (1) documenting wing ice shape by stereo photography, (2) measuring section drag for the iced wing with a wake probe, and (3) continuation of the work described in NASA TM-83564 ${ }^{4}$ which deals with measuring the overall performance loss of the aircraft caused by ice and the contributions of var1ous iced airframe components to the overall drag increase. In addition, measurements of the corresponding icing environments are reported and related to the FAR Part 25, Appendix C, certification criteria.

A short film is avallable which documents the NASA icing research fioght program. 5

\section{The Aircraft}

The icing research aircraft is a typical twon engine commuter type aircraft. It has PT6A-20A turbine engines (which generate 550 SHP each at sea level standard conditions) driving three bladed propellers. Maximum gross weight is 11,000 lbs. Long range cruise speed is 127 KTAS at $10,000 \mathrm{ft}$, standard day, and maximum gross weight.

The aircraft is equipped with electrothermal anti-icers on the propellers, engine inlets, and windshield. Pneumatic deicer boots are located on the wing outboard of the engine nacelles, on both horizontal and vertical stabilizers, on the wing struts, and on the rear landing gear struts (the aircraft has fixed landing gear). The pneumatic delcers located on the vertical stabllizer, wing struts, and landing gear struts are nonstandard 
items allowing additional capability in measuring component drag through selective deicing.

\section{Instrumentation}

\section{Icing Cloud Parameters}

Measurements were made of cloud liquid water content, volume median diameter droplet size, droplet size distribution, air temperature, reference ice accretion rate, duration of the icing encounter, and flight speed. Icing environment data from electronic sensors were recorded on a digital tape recorder. See Fig. 1 for instrument locations on the aircraft.

\section{Instrumentation included:}

For liquid water content: Johnson and Williams (J-W) heated wire probe, ${ }^{6}$ produced by Cloud Technology.

For cloud droplet size distribution and volume median diameter: rotating multicylinder ${ }^{7}$ and sooted slide droplet catcher.

For air temperature platinum resistance total temperature probe, ${ }^{8}$ produced by Rosemount, Inc.

For reference ice accretion: Pressure-type Icing Rate and Accretion Meter ${ }^{9}$ (PIRAM), developed by NACA.

It should be noted that icing cloud parameters are difficult to measure. Accuracy is difficult to determine and absolute calibration standards are lacking. Measurements were not, in general, corrected for local flow field effects caused by the presence of the aircraft. The philosophy of this report is to correlate avallable icing cloud data and ice accretion properties with corresponding ice shapes and aerodynamic data. For further details about icing instrument results see Ref. 2 .

\section{Stereo Photography System}

Employing technology developed by the U.S. Air Force Arnold Engineering and Development Center (AEDC), $10,11,12$ NASA Lew 1 s personnel designed and built a wing stereo photography system for the icing research aircraft. The objective of the system was to obtain stereo pair photo images of the wing's iced leading edge that would enable measurement of the ice surface through photogrammetric analysis to generate profiles of the ice shape with a minimum acceptable resolution of +0.03 in $(+0.04$ percent chord). The system's cameras are two Hasselblad $70 \mathrm{~mm}$ format motor drive units with 250 $\mathrm{mm}$ lenses mounted in the nose of the aircraft behind optical glass viewports (Fig. 2(a)). The cameras' fields of view encompassed a common portion of the wing leading edge located at about 69 percent of the semispan. To provide spatial references in the photo-images needed for photogrametric analysis, an array of control points was painted on the wing leading edge section and the wing fence. The points' precise positions were then measured and catalogued. The control point array with general dimensions is diagrammed in Fig. 2(b). To increase contrast and character of the ice surface in the image, a $2000 \mathrm{~W} / \mathrm{sec}$ flash unit which sidelighted the viewfield was discharged during the exposure. An electronic control system was used to synchronize the shutters and flash.
The system was activated from a switch at the copilot's station. The photo images were positive color exposures on Kodak Ektachrome ${ }^{R}$ ASA $64 \mathrm{fl} l \mathrm{~m}$.

Photogrammetric anaiysis of the ice accretion images was performed using a $K$ and $E$ DSC $3 / 80 \mathrm{com}-$ puterized analytical compiler system. An analysis of the images under high magnification would generate a finely spaced array of ice surface spot measurements. These measurements were made over approximately a 10 in spanwise section of the wing, concentrating on ice peaks and valleys in order to get a measure of ice surface roughness. Each measurement's spacial coordinates were then plotted on one composite profile view expressing the representative shape and roughness of the ice accretion.

Wing Wake Survey Probe and Surface Pressure Belt System

The wing wake survey probe and surface pressure belt system was designed and built by the ohro State University, Columbus, Ohio. The wake survey probe consists of a geared, motor driven probe, with separate pitot and static probe tips located $1 / 4$ chord aft of the wing trailing edge at about 69 percent of the semispan. The probe can traverse an arc of $180^{\circ}$ through the wing wake (Figs. 1 and $3)$. The probe is driven by a stepper motor in the wing. Static and total pressures are measured in the wing wake along with the corresponding probe position in the wake. Pressures are measured by transducers located in the cabin. A minicomputer is used as a controller and data logger. The computer calculates wing section drag coefficients by using momentum theory (the velocity deficit in the wing wake is related to the drag of the wing section). During icing flights, heaters in the wake probe kept the probe free of ice and a nitrogen purge system kept pressure lines clear of water.

A pressure belt is located at the same spanwise wing station as the wake probe, but on the opposite wing (Fig. 4). The pressure belt measures wing surface static pressures during clear air flights and consists of strip-a-tubes wrapped around the wing. Static pressure holes are located on the pressure belt around the wing surface. Each static hole has a pressure line feeding into the cabin. A Scanivalve $\mathrm{R}^{\mathrm{i}}$ is employed to read the pressures. Cutoff valves are used to instantaneously trap all pressures in the lines before the pressures are read. Data can be reduced "on line" during a flight or on a post flight basis. The on line data reduction capability allows real time evaluation of data quality. Raw data are processed more accurately at the Ohro State Aeronautical and Astronautical Research Laboratory on their Harris/4 computer than can be in flight. See Refs. 13 and 14 for a more complete discussion of the wake survey and pressure belt system.

\section{Aircraft Performance Instrumentation}

Aircraft performance measurements were made with calibrated service system instruments. The only instrument used that was not part of the ship's service system was the heated angle of attack probe. Performance data was recorded manually. Instrumentation included:

\section{Engine torque Edison Torque Pressure Gauge $\left(1 b / 1 n^{2}\right)$}

Propeller RPM: General Electric (percent) 
Pressure Altitude: Aerosonic Encoder ( $\mathrm{ft}$ ) Indicated Airspeed. Bendix Pioneer (kn) Angle of Attack. Specialties, Inc. (deg)

\section{Flight Test Procedures}

The aircraft was flown in clear air to establish an uniced performance baseline in terms of a lift curve and drag polar. Steady, level, performance methods (speed/power measurements) were employed.15 The uniced lift curve and drag polar were derived to establish a basis for comparison between the iced versus uniced aircraft (see Aircraft Performance Loss Due to Ice section).

The wake survey and pressure belt system was also flown in clear air to establish an uniced baseline in terms of a wing section lift curve and drag polar. Wake probe measurements were made on the right wing while wing surface pressure measurements were made at the same spanwise location on the left wing. The wing pressure belt was never used in icing conditions.

The general procedure during icing flights was (1) accrete ice while measuring the icing environment, (2) exit the roing cloud and document the wing ice shape with stereo photography, (3) measure the increase in wing section drag with the wake survey probe, (4) measure the decrease in overall aircraft performance, and (5) selectively deice a irframe components and obtain drag decrements.

Airframe ice was accreted at cruise firght conditions (approx. 135 KTAS). While in icing, a relatively constant cruise airspeed was maintained by slowly increasing power; however, in heavy icing, once maximum continuous power was reached, a speed decay of 10 to 15 KIAS would sometimes occur. Icing instrumentation continuously measured icing cloud parameters. The pneumatic deicers on the wings, empennage, and struts were not activated during the icing encounter; however, propeller and engine inlet heaters were always kept on. After a sufficient amount of ice had been accreted on the airframe, the aircraft would be flown to exit the icing area. Generally, the quickest means was to climb and fly above the icing cloud.

At this point, level flight speed/power measurements as well as wake survey measurements were made. The first speed/power measurements were made with the aircraft all iced, excluding propellers and engine inlets. Subsequent speed/power series were made after selectively deicing airframe components in order to establish various component contributions to the overall drag. If it was determined visually that ice was shedding during the measurements, the series would be abandoned. Measurements were not attempted unless the aircraft was totally free of ice prior to the icing encounter. That is, all ice on the aircraft was due solely to the documented icing encounter. All performance measurements were made with flaps up $\left(\delta \mathrm{F}=0^{*}\right)$.

Wake survey measurements of the iced wing were made alternately with speed/power measurements. During wake survey runs the aircraft was flown at constant airspeed and angle of attack. It took about $160 \mathrm{sec}$ for the wake probe to traverse behind the wing while taking data.
Stereo photographs were taken just prior to or during wake survey measurements and speed/power measurements.

\section{Results and Discussion}

Nineteen icing research flights were flown during the 1983/84 season. To avoid repetition and to focus in on key results, data from five icing flights are presented herein. These flights are referred to by their numbers and were chosen for the following reasons. Flight $84-19$ provided aircraft performance measurements which included some component deicing. Flight 84-27 provided a severe glaze icing encounter after which both aircraft performance and wake survey measurements were made. Flight 84-34 provided the most complete set of data which included stereo photographs, performance measurements, and wake survey measurements. Discussed in less detall are Flights 84-29 and 84-32 which along with Flight 84-34 provided stereo photography data showing a correlation of ice accretion extent on the wing surface with droplet size.

The following results and discussion are organized by the subjects: characterization of icing encounters, ice shape documentation with stereo photography, wing section drag increase due to ice, and aircraft performance loss due to ice.

\section{Characterization of Icing Encounters}

Aerodynamic measurements and stereo photographs of ice shapes taken following an icing encounter are referenced to those icing cloud parameters that created the 1 cing condition. Icing environment observations and measurements are presented in Table I under two categories: the basic icing cloud variables and the properties of the ice accretions. Measured cloud variables include liquld water content, droplet size distribution, median volume diameter, temperature, and the duration and extent of the icing. Ice accretion properties include icing rate, reference amount of ice accreted, and the shape of the ice formation as determined by observation. Plots of cloud liquid water content versus time during the $1 \mathrm{cing}$ encounter are given in Fig. 5 for Flights $84-19,27$, and 34.

The icing encounter is characterized by two approaches. The first approach relates the encounter to its frequency of occurrence. Lewis and Bergrun 16 presented charts showing the probability of specific icing conditions. For example, the LWC measured on Flight $84-19\left(0.30 \mathrm{~g} / \mathrm{m}^{3}\right)$ would be equalled or exceeded in only 1 out of $4501 \mathrm{cing}$ encounters when found in combination with the other measured icing parameters (table I). This low probability stems primarily from the unusual duration of the rcing produced by the flight test procedure of holding within the icing cloud. The second approach for characterizing the icing encounter involves the FAR Part 25 icing parameter envelopes.

For many years the extremities of $1 \mathrm{cing}$ cond 1 tions have been gaged by the FAR Part $25 \mathrm{icing}$ parameter envelopes used to design and certify aircraft. Thus, it is of interest to assess the intensity of a given icing encounter in relation to these envelopes. Figure 6 from FAR Part 2517 gives the maximum liquid water content to be found 
continuously in stratiform clouds as related to mean effective drop diameter, air temperature, and horizontal extent of the icing encounter. This FAR envelope of maximum conditions is for a standard distance of $20 \mathrm{mrles}(17.4 \mathrm{n} \mathrm{ml})$. For icing encounter distances other than the standard distance, the maximum liquid water content may be increased or decreased depending on whether the encounter distance is shorter or longer than the standard distance. Data have shown that the higher the average liquid water content of an $1 \mathrm{cing}$ encounter, the more localized the encounter will be. A liquid water content correction factor relating maximum liquid water content with horizontal distance has been developed from previous data gathered by NACA (Figs. $6(a)$ to $(c)$ ). The maximum liquid water content is modified by multiplying values of maximum liquid water content for the standard distance by the appropriate LWC correction factor determined for the actual distance flown in icing.

Data from Flights $84-19,27$, and 34 are referenced to the FAA design and certification envelopes in Figs. 6(a) to (c) (Flights $84-29$ and 32 are not referenced to the certification criteria since no performance data are presented for these flights.) Shown in Fig. 6(a), for example, are the design envelopes and the icing encounter data of Flight 84-19. The measured values of mean effective droplet diameter $(11 \mu \mathrm{m})$ and liquid water content $\left(0.3 \mathrm{~g} / \mathrm{m}^{3}\right.$ ) are plotted on the top graph (solid symbol). The actual horizontal distance gives an LWC correction of 0.43 . The air temperature measured in this icing encounter was $-6.8^{\circ} \mathrm{C}\left(19.8^{\circ} \mathrm{F}\right)$, which for a mean effective droplet diameter of $11 \mu \mathrm{m}$, gives a maximum liquid water content of $0.8 \mathrm{~g} / \mathrm{m}^{3}$ (as shown by the interpolated value (dotted line) on the top graph). But this maximum $i$ iquid water content is for the standard distance and should be reduced by the LWC correction factor of 0.43 to $0.34 \mathrm{~g} / \mathrm{m}^{3}\left(0.43 \times 0.8 \mathrm{~g} / \mathrm{m}^{3}\right)$. This is shown by the solid line on the top graph. Comparing the maximum value of $0.34 \mathrm{~g} / \mathrm{m}^{3}$ to the measured value of $0.3 \mathrm{~g} / \mathrm{m}^{3}$, we find that the measured value was 88 percent of the maximum $(0.30 / 0.34)$ as given in Table I. Figures $6(b)$ and (c), Flights 84-27 and 84-34 respectively, were constructed by employing the same procedure.

The correction factor relating maximum LWC with distance is of primary interest in determining the amount of ice which can accumulate on unprotected surfaces during an icing encounter. However, for design of most ice protection systems, the maximum LWC (from the FAR Part 25 Appendix C) for the standard distance $(17.4 \mathrm{~nm})$ is used.

Ice accretion shapes are documented by photographs for Flights $84-19,27$, and 34 , and are presented in Figs. 7 to 9 . The photographs show examples of ice accretions on various components of the airframe including the wing, tail, struts, wheels, and antenna.

\section{Ice Shape Documentation With Stereo Photography}

Stereo photography results from Flights $84-29$, 32 , and 34 are presented in this section. For Flights 84-19 and 27, camera system problems produced degraded image quality that prevented acceptable analysis accuracy. The minımum acceptable resolution band was t0.03 $\mathrm{in}$. Overall, of the approximately 50 stereo pairs that were taken during the season: 25 percent allowed measurements within the acceptable resolution band, 50 percent gave results with unacceptable resolution, and 25 percent could not be analyzed. This success rate is a reflection of the fact that the system was being developed throughout the season.

Figures 10 and 11 show examples of stereo pair analysis. Each of the profile views presents the contour of the wing leading edge with the ice accretion surface represented by data points. As discussed previously, each data point represents a measured position on the ice surface within about a 10 in spanwise band. Thus, the profile is a composite ice profile representing shape and roughness. Clustering of the points gives a measure of ice surface roughness over this spanwise section. Approximately 75 points were measured from each stereo pair to define a representative ice surface profile.

Figure 10 presents a series of profiles, from Flight 84-34, which show that the ice accretion was undergoing sublimation and erosion. Sublimation is when the ice changes directly from a solid to a vapor. Erosion refers to the process where portions of the ice, particularly the ice feathers, become structurally weak enough (by sublimation or the sun's radiation) that the aerodynamic forces break them off the ice accretion. This occurred after the icing encounter during the period in which derodynamic measurements were taken. Some ice feathers and the small "upper horn" of the ice accretion disappeared after a period of $37 \mathrm{~min}$. The temperature during this time was cold $\left(-11{ }^{\circ} \mathrm{C}\right.$ static, $\left.12.2^{\circ} \mathrm{F}\right)$. The aircraft was flying above the clouds in the sun with an average true airspeed and pressure altitude of 126 KTAS and $8250 \mathrm{ft}$, respectively. Ice sublimation and erosion affect the aerodynamic measurements. Flying in between cloud layers, out of the sun, is best when possible. The aerodynamic data acquisition time should be reduced in order to minimize the problem.

Additional stereo photography results, from Flights $84-29,32$, and 34 , are presented in Fig. 11 and show a correlation of ice accretion extent $11 \mathrm{~m}-$ its with droplet size measurements. The profiles exhibit a definite variability in the extent of the ice accretion on the upper and lower surfaces. Ice accretion extent is related to droplet impingement limits. At the nearly constant conditions of airspeed and altitude that were flown, the different impingement limits would primarily be a function of the cloud droplet sizes. Figure 11 shows that the wide range of droplet sizes measured during the encounters did, in fact, produce large changes in impingement area. Very small droplets created a narrow ice accretion (FLT 84-32) whereas much larger droplets gave a wide ice band along the leading edge (FLT 84-29). Droplet sizes were measured either by the rotating multicylinder method (RMC) or by exposure of sooted slides. Both measurements were analyzed for the volume median droplet size (or mean effective in the case of the RMC measurements), 7 distribution of the sizes, and maximum droplet size determined by the distribution as defined by Langmuir in the RMC analysis procedure. An E distribution was common to the examples shown in Fig. 11. As a result, the maximum droplet size, which determines the ilmits of impingement, is the same multiple of the volume median for each of the three examples. 
Wing Section Drag Increase Due to Ice

Results of the uniced baseline tests for the wake survey and pressure belt system are shown in Figs. 12 and 13. Figure 12 shows a plot of wing section lift coefficient versus aircraft angle of attack. It should be noted that this is not the local angle of attack at the wing, rather, it is the aircraft angle of attack referenced to the floor line. The wing is at a $2.5^{\circ}$ inclination to the floor ine and is also subject to an induced angle of attack effect. Figure 13 shows the wing section drag coefficient versus the wing section 1 ift coefficlent for the uniced wing. This measured drag polar exhibits an unusual plateau at section $C_{1}$ 's from about 0.65 to 0.9 . It should be noted that the aircraft has NACA type doubleslotted flaps on the full span with the outboard tralling sections being allerons (wake survey measurements were made on the outboard region).

Icing data are presented and compared to uniced measurements. Iced wing section $c_{d}$ measurements are plotted against aircraft angle of attack, rather than $C_{l}$, since the pressure belt was not used in icing conditions. In Fig. 14, wing section drag coefficient versus aircraft angle of attack for icing Flights 84-27 and 84-34 is plotted and compared to the uniced wing drag data to lllustrate the drag increase caused by ice. The largest drag measurements were recorded on Firght 84-27, which was a severe glaze icing encounter. At an angle of attack of $3.1^{8}$, with an airspeed of 121 KTAS, the drag increased 56 percent over the faired baseline. At an angle of attack of $6.0^{\circ}$, with an airspeed of 101 KTAS, the drag Increased by 120 percent over the baseline. The other icing flight shown, Flight 84-34, shows a much smaller drag increase. At an angle of attack of $0.9^{\circ}$, with an a)rspeed of 148 KTAS, the drag increased 6 percent over the baseline. At an angle of attack of $7.2^{\circ}$, with an airspeed of 97 KTAS, the drag increased 19 percent over the baseline. The magnitude of the drag increase is a function of the amount of ice on the wing, the ice shape, and the ice roughness. From photographs (Figs. $8(a)$ and $9(a)$ ), it can be seen that the $1 \mathrm{ce}$ on Flight $84-27$ was a great deal rougher than that on Flight 84-34. The wake survey measurements from Flight 84-34 were made during the time period beginning $12 \mathrm{~min}$ after the $1 \mathrm{cing}$ encounter and ending $30 \mathrm{~min}$ later. The shape of the ice accretion during this period was documented with stereo photography and is presented in Fig. 10 .

The efforts reported herein represent the first attempt to perform in-flight measurements of wing section drag increases caused by ice accretions. The unusual form of the uniced drag polar suggests that additional work should be done to more thoroughly understand and verify the measurements; nevertheless, the wake survey probe did detect significant increases in drag and therefore warrants continued future effort.

\section{Aircraft Performance Loss Due to Ice}

The baseline lift curve and drag polar for the uniced aircraft were obtained to establish a basis for $11 \mathrm{ft}$ and drag coefficient comparisons between the iced versus uniced aircraft ( $F$ gs. 15(a) and (b)). Baseline performance measurements from the $1983 / 84$ season show a slight shift towards lower drag from those reported in Ref. 4. The exact reason for the shift is unknown. However, since the interest lies in measuring performance differences, the 1983/84 icing data are compared to the 1983/84 uniced baseline data. Next, performance data from three icing flights are presented as well as a discussion on engine out capability.

Flight 84-19. Flight 84-19 was flown in glaze icing conditions with LWC of $0.3 \mathrm{~g} / \mathrm{m}^{3}$, static temperature of $-6.8{ }^{\circ} \mathrm{C}$, and an encounter time of 49 min. Figure 7 shows photographs of resulting ice accretions on the aircraft. The aircraft exited the icing cloud at $5700 \mathrm{ft}$ for a series of performance measurements. S1x steady-state performance measurements were made taking a total of 30 min to complete. Results are plotted on $C_{L}$ versus $\alpha$ and $C_{D}$ versus $\left(C_{L}\right)^{2}$ graphs shown in Figs. 16(a) and (b). Referring to Fig. 16(b), three measurements were made with the aircraft all iced. At $C^{2}=0.25$, the all iced aircraft showed a 31 percent increase in drag over the uniced baseline. The next three measurements were made with the wing struts and landing gear struts deiced. By faring a line through these three data points and looking at $C E=0.25$, the drag is reduced to 18 percent over the baseline. This drag reduction appears too large since it corresponds to 42 percent of the total drag caused by ice. If the low data point at $c^{2}=0.4$ is ignored, and another line drawn, then the drag reduction becomes 22 percent over the uniced baseline. Thus, the ice on the wing struts and landing gear struts contributed about 29 percent of the total drag increase due to ice. Ice also caused a decrease in $17 \mathrm{ft}$ as shown on Fig. 16(a). At an angle of attack of $6^{\circ}$ the lift coefficient is about 12 percent lower than the uniced baseline.

The performance measurements quoted above took place over a period of $23 \mathrm{~min}$. Conventional photographs taken during this time indicate that some ice sublimation or erosion occurred. Stereo photographs were not avallable for this flight. The amount of reduction in drag due to sublimation and erosion is unknown. Although the general ice shape remained, the characteristic roughness was reduced.

Flight 84-27. Flight 84-27 was flown in mixed (1.e., rime/glaze) icing conditions for 25 min with LWC of $0.34 \mathrm{~g} / \mathrm{m}^{3}$ and static temperature of $-5.2{ }^{\circ} \mathrm{C}$. Figure 8 shows photographs of resulting ice accretions on the aircraft. Ice degraded the aircraft performance significantly. Three measurements were made with the aircraft all iced. Figures $17(a)$ and (b) show plots of $C_{L}$ versus $a$ and $C_{D}$ versus $C^{2}$. The drag increase for the all iced aircraft was very large. Referring to Fig. 17(b), at $C=0.25$, it can be est $1-$ mated that the drag increased to 75 percent over the uniced baseline. The ice also caused a decrease in lift. Referring to Fig $17(a)$, at an angle of attack of $6^{\circ}$ the lift coefficient is 16 percent lower than the uniced baseline. Sublimation of the ice accretion was not a problem since the aircraft was not in the sun.

Flight 84-34. Flight 84-34 was flown in mixed icing conditions (1.e., mixture of rime and glaze) for $22 \mathrm{~min}$, with LWC of $0.58 \mathrm{~g} / \mathrm{m}^{3}$, and static temperature of $-6.5{ }^{\circ} \mathrm{C}$. Figure 9 shows photographs of resulting ice accretions on the aircraft. Data plots are shown in Figs. 18(a) and (b). Three measurements were made with the aircraft all iced. Referring to $F_{19} 18(\mathrm{~b})$, at $C E=0.25$ the 
drag increased for the all iced aircraft to 38 percent over the uniced baseline. Two measurements were made with the wings deiced. With the wings deiced, at $C^{2}=0.25$, the drag was 26 percent over the baseline. Thus, at $C^{2}=0.25$, the ice on the delcabie portion of the wings contributed 32 percent of the total drag increase due to ice. One measurement was made with the empennage and wings deiced and resulted in a drag of 22 percent over the baseline. Thus, ice on the empennage contributed approximately 11 percent of the total increase in drag due to ice. Ice also caused a decrease in lift. Referring to Fig. 18(a), at an angle of attack of $6^{\circ}$, the lift coefficient is about 11 percent lower than the uniced baseline. Sublimation of the ice accretion was documented and discussed previously in the Stereo Photography section. Performance data was acquired during the time period beginning $10 \mathrm{~min}$ after the $1 \mathrm{cing}$ encounter and ending $49 \mathrm{~min}$ later (refer these times to the times of the stereo profiles shown in Fig. 10).

Engine out capability with ice. For Flight 84-27, thrust horsepower versus velocity plots were developed to present the effect of glaze icing on engine out performance. These plots were constructed by comparing the two engine flight derived thrust horsepower required curves for the uniced and iced aircraft against a calculation of one engine thrust horsepower available. One engine THP avallable was calculated by using (1) maximum continuous power setting charts in the pllots handbook with 100 percent propeller rpm at sea level and 96 percent propeller rpm at any altitude, and (2) propeller efficiency charts to calculate propeller efficiencies used to obtain THP. Trim drags caused by asymmetric thrust were measured on the uniced aircraft by feathering one propeller and were found to be negligible; 1.e., within the scatter of our baseline measurements. Engine out capability in this discussion refers to power requirements and does not address possible handling qualities problems caused by an engine out with iced control surfaces.

For the uniced aircraft, Fig. 19(a) shows the baseline thrust horsepower required versus velocity for standard day, standard weight, and sea level conditions. For icing Firght 84-27, Fig. 19(b) shows approximate engine out capability where data has been corrected to standard day, standard weight, and sea level conditions. Figure 19(c) shows engine out capability for Flight 84-27 at test altitude conditions and standard weight. The results show that the glaze ice accretion of Flight 84-27 increased the required thrust horsepower enough that the engine out capability of the aircraft was seriously reduced. Although further measurements were attempted after selective deicing of the wings and empennage, test conditions were not conducive to acquiring data. Based on our experience from past measurements 4 , deicing the wings, empennage, wing struts, and landing gear struts would have provided safe engine out capability.

In general, it can be seen that glaze ice conditions can rapidly erode engine out capability. Undesirable conditions would exist if an ice protection system reduced the drag an insufficient amount such that it could not provide engine out capability at any altitude, or if it provided engine out capability only at dangerously low altitudes. Such would be the case if an ice protection system failed or did not protect a sufficient area of the aircraft.

\section{Conclusions}

1. It has been shown that stereo photography can be used as a means to measure natural ice shape profiles in the flight environment.

2. It has been shown that a wake survey probe can be used in flight to measure increases in wing section drag caused by natural ice.

3. The time required for aerodynamic data acquisition must be reduced in order to minimize errors caused by ice sublimation and erosion.

4. Glaze ice affects the performance of aircraft far more seriously than rime or mixed ice (1.e., combination of rime and glaze).

5. Glaze ice can rapidly erode engrne out capability if an ice protection system fails or does not protect a sufficient area of the aircraft in order to reduce enough of the drag increase caused by ree.

\section{Acknowledgements}

AEDC's Dick Palko and Pat Cassady provided guidance enabling Lewis to build a stereo camera system for the aircraft. They also analyzed stereo pair images to generate the ice shape profiles. Ohio State University designed and built the wake survey and pressure belt system. Jerry Gregorek, Rick Frueler, and Mike Hoffmann put a great deal of work into making the system operational and in processing data. The B.F. Goodrich Company of Akron, Ohio, supplied pneumatic deicer boots for the vertical stabilizer, wing struts, and landing gear struts.

\section{References}

1. Reinmann, J.J., Shaw, R.J., and 01 sen, W.A., Jr., "NASA Lew1s Research Center's Program on Icing Research," NASA TM-83031, 1983.

2. Ide, R.F., and Richter, G.P., "Evaluation of Icing Cloud Instruments for 1982-83 Ic ing Season Flight Program," AIAA 84-0020, January 1984.

3. Shaw, R.J., "Progress Toward the Development of an Aircraft Icing Analysis Capability," NASA TM-83562, 1984.

4. Ranaudo, R.J., Mikkelsen, K.L., Mcknight, R.C., and Perkins, P.J., Jr., "Performance Degradation of a Typical Twin Engine Commuter Type Aircraft in Measured Natural Icing Conditions," NASA TM-83564, 1984.

5. "Flight Research in Natural Icing Conditions," NASA f $11 \mathrm{~m}$ serial number $\mathrm{C}-314,1984$.

6. Nee1, C.B., Jr., and Steinmetz, C.P., "The Calculated and Measured Performance Characteristics of a Heated-Wire Liquid-Water-Content Meter for Measuring Icing Severity," NACA TN-2615, 1952. 
7. Brun, R.J., Lewis, W., Perkins, P.J., and Serafinı, J.S., "Impingement of Cloud Droplets on a Cylinder and Procedure for Measuring Liquid-Water Content and Droplet Sizes in Supercooled Clouds by Rotating Multicylinder Method," NACA TR-1215, 1955.

8. Lewis, W., "A Flight Investigation of the Meteorological Conditions Conducive to the Formation of Ice on Airplanes," NACA TN-1393, 1947.

9. Perkins, P.J., McCullough, S., and Lewis, R.D., "A Simplified Instrument for Recording and Indicating Frequency and Intensity of Icing Conditions Encountered in Flight," NACA RM-E51E16, 1951.

10. Palko, R.L., and Cassady, P.L., "Photogrammetric Development and Application at AEDC," AIAA Paper 82-0610, 1982.

11. Palko, R.L., and Cassady, P.L., "Photogrammetric Analysis of Ice Buildup on a U.S. Army UH-1H Helicopter Main Rotor in Hover Flight," AEDC-TR 83-43, October 1983.

12. Palko, R.L., Cassady, P.L., Mcknight, R.C., Freedman, R.J., "Initial Feasibility Ground Test of a Proposed Photogrammetric System for Measuring the Shapes of Ice Accretions on Helicopter Rotor Blades During Forward Flight," AEDC-TR 84-10, Aug. 1984.
13. Gregorek, G.M., Hoffmann, M.J., Weislogel, G.S., "Data Acquisition System for In-flight Airfoll Evaluation." SAE Paper No. 760462, 1976.

14. Gregorek, G.M., Hoffmann, M.J., Welslogel, G.S., and Vogel, G.M., "In-flight Measurements of the GA (W)-2 Aerodynamic Characteristics," SAE Paper 770461, March 1977.

15. Lush, K.J., and Moakes, J.K., "Performance Reduction Methods for Turbo-Propeller Aircraft," pp. 5:1-20; Dommasch, D.0., "Data Reduction and Performance Test Methods for Reciprocating Engine Aircraft," pp. 6:1-47, AGARD Flight Test Manual, 2nd revised ed., Vol. I, edited by E.J. Durbun and C.D. Perkins, Pergamon Press, Oxford, 1962.

16. Lew1s, W. and Bergrun, N.R., "A Probability Analysis of the Meteorological Factors Conducive to Aircraft Icing in the United States," NACA TN-2738, 1952.

17. "Ice Protection," Airworthiness Standards: Transport Category Airplanes, F.A.A. Regulations Part 25, Section 25.1419, and Append $1 x$ C, 1974 . 
TABLE I. - ICING CLOUD DATA AND ACCRETION PROPERTIES FOR ICING FLIGHTSa

\begin{tabular}{|c|c|c|c|c|}
\hline & & \multicolumn{3}{|c|}{ Flight number } \\
\hline & & $84-19$ & $84-27$ & $84-34$ \\
\hline & & \multicolumn{3}{|c|}{ Flight date } \\
\hline & & $2 / 3 / 84$ & $3 / 15 / 84$ & $4-18-84$ \\
\hline \multicolumn{5}{|c|}{ Flight data } \\
\hline $\begin{array}{l}1 \\
2 \\
3 \\
4\end{array}$ & $\begin{array}{l}\text { Average pressure altitude, ft } \\
\text { Average true airspeed, kn } \\
\text { Average aircraft angle of attack, deg } \\
\text { (referenced to aircraft floor line) } \\
\text { Start time of icing encounter }\end{array}$ & $\begin{array}{r}5306 \\
134 \\
1.4^{\bullet} \\
14: 16\end{array}$ & $\begin{array}{r}8526 \\
137 \\
2.2^{\bullet} \\
12: 39\end{array}$ & $\begin{array}{r}5578 \\
137 \\
1.6^{\circ} \\
10: 40\end{array}$ \\
\hline \multicolumn{5}{|c|}{ Icing cloud data } \\
\hline $\begin{array}{l}5(a) \\
5(b) \\
6(a) \\
6(b) \\
7(a) \\
7(b) \\
8(a) \\
8(b) \\
8(c) \\
9\end{array}$ & $\begin{array}{l}\text { Total temperature, }{ }^{\circ} \mathrm{C} \\
\text { Static temperature, }{ }^{\mathrm{C}} \\
\text { Average LWC, gms/cu m } \\
\text { Maximum LWC, gms/cu m } \\
\text { Duration of encounter, min } \\
\text { Extent of encounter, } n \mathrm{mr} \\
\text { Mean effective droplet diameter, } \mu \mathrm{m} \\
\text { Droplet size distribution } \\
\text { Maximum droplet size, } \mu \mathrm{m} \\
\text { Cloud type }\end{array}$ & $\begin{array}{r}-5.2 \\
-6.8 \\
0.30 \\
0.70 \\
49 \\
110 \\
11 \\
\mathrm{E} \\
30 \\
\text { Stratus }\end{array}$ & $\begin{array}{r}-3.5 \\
-5.2 \\
0.34 \\
0.70 \\
25 \\
57 \\
15 \\
\mathrm{E} \\
41 \\
\text { Stratus }\end{array}$ & $\begin{array}{r}-4.8 \\
-6.5 \\
0.58 \\
0.90 \\
22 \\
50 \\
10 \\
E \\
27 \\
\text { Strato-Cu }\end{array}$ \\
\hline \multicolumn{5}{|c|}{ Ice accretion properties } \\
\hline $\begin{array}{l}10 \\
11 \\
12 \\
13 \\
14 \\
\text { (a) } \\
\text { (b) }\end{array}$ & $\begin{array}{l}\text { Type of ice (see photo) } \\
\text { Shape of ice (see photo) } \\
\text { Average reference accretion rate, in/hr } \\
\text { Reference total accretion, in } \\
\text { Characterization of icing } \\
\text { Frequency of occurrence } \\
\text { (number of icing encounters to equal or } \\
\text { exceed) } \\
\text { Certification criteria } \\
\text { (percent of max (WC) }\end{array}$ & $\begin{array}{r}\text { Mix } \\
2.9 \\
2.4 \\
\\
1 \text { in } 450 \\
88\end{array}$ & $\begin{array}{r}\text { G1aze } \\
\begin{array}{r}3.4 \\
1.4\end{array} \\
1 \text { in } 150 \\
79\end{array}$ & $\begin{array}{r}M 1 X \\
5.8 \\
2.1\end{array}$ \\
\hline
\end{tabular}

aSee reference 4 for complete explanations of table elements. 

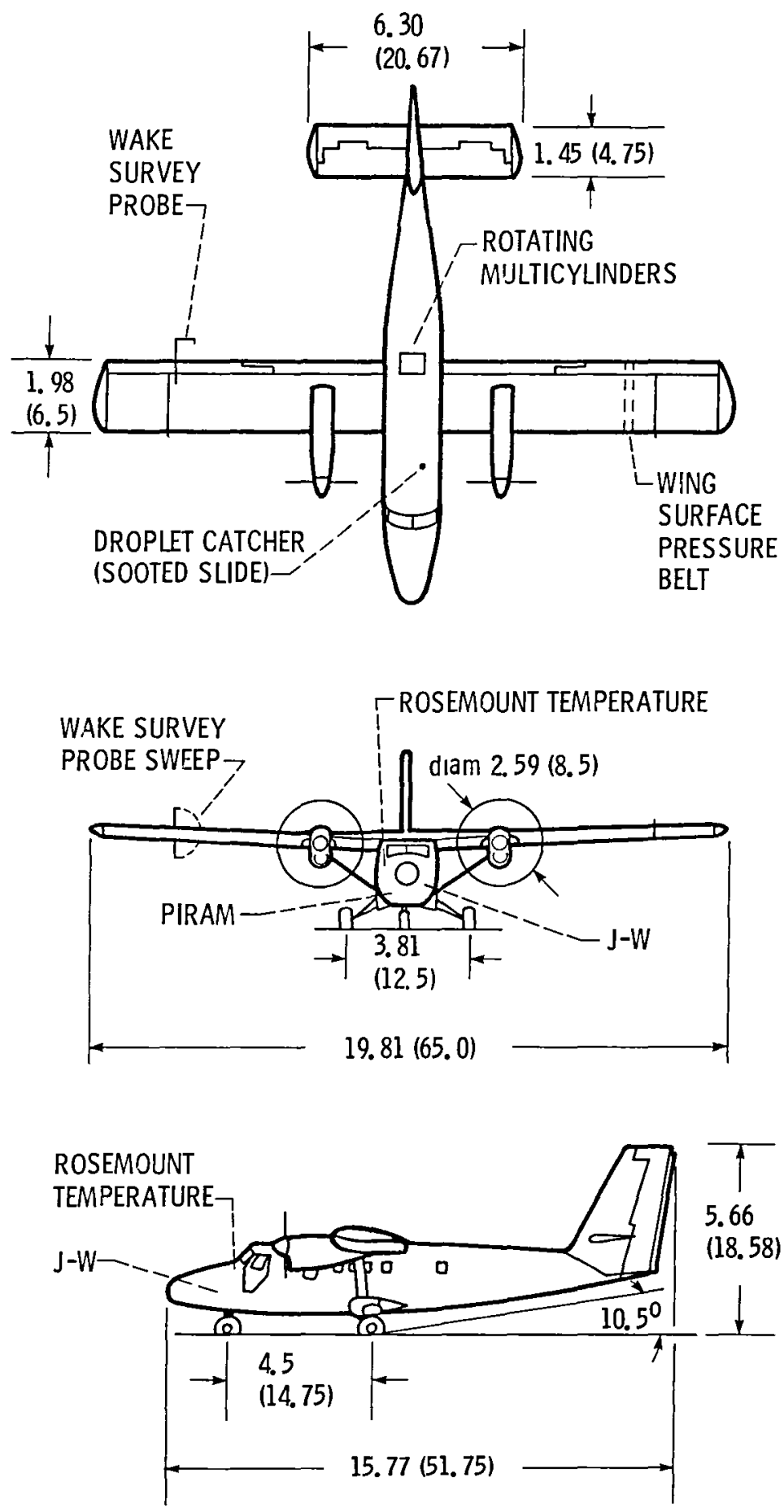

Figure 1. - NASA LewIS Research Center IcIng research aircraft and locations of IcIng instruments, wake survey probe, and wing surface pressure belt. All dimensions are in $\mathrm{m}(\mathrm{ft})$. 

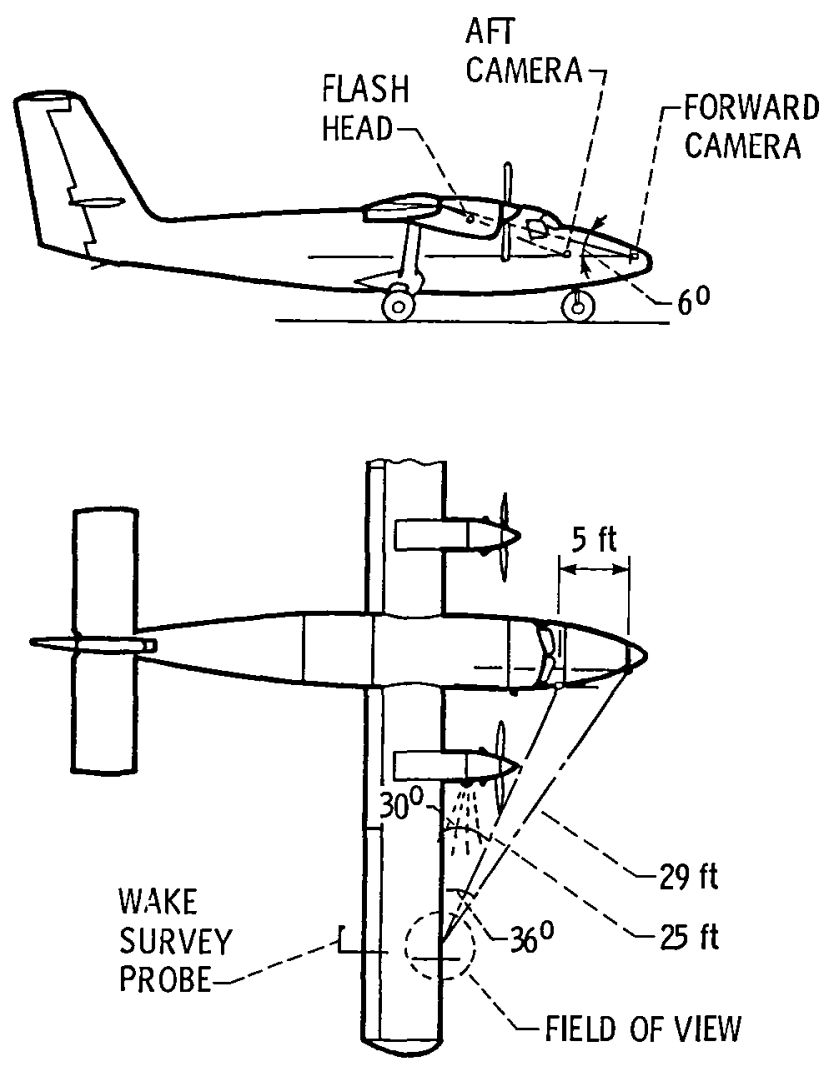

(a) Stereo camiera system layout.

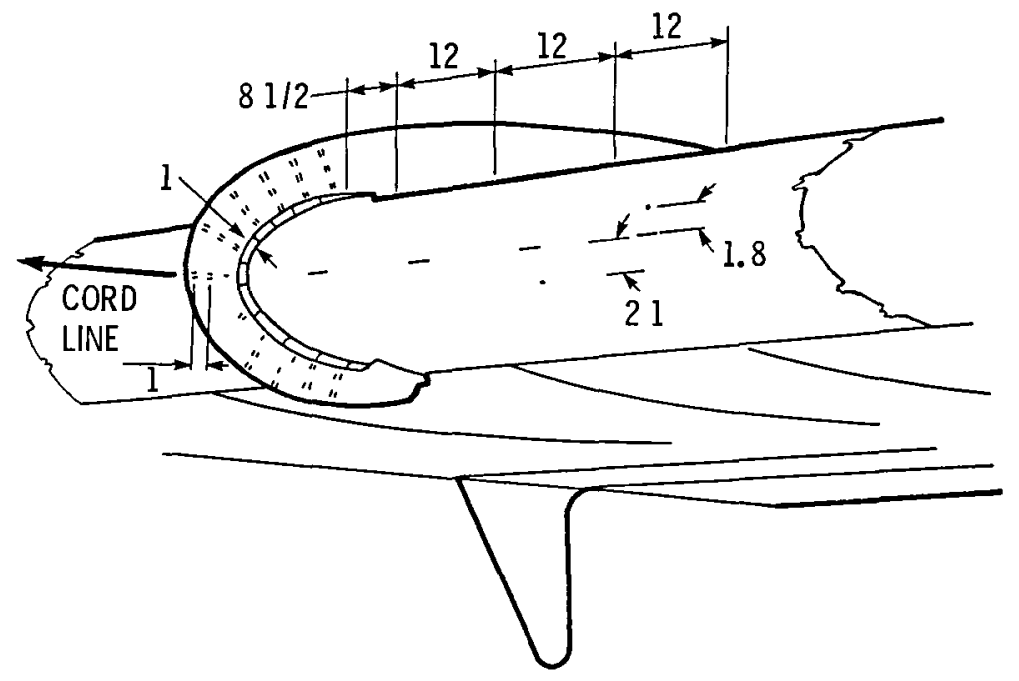

(b) Reference control points on wing surface and wing fence used in analyzing stereo pair photographs. Dimensions are in in. Control points on wing fence positioned on lines that intersect the wing surface at $2 \%$ chord spacing.

Figure 2. - Stereo camera system used to document ice shape on wing ahead of wake survey probe. 


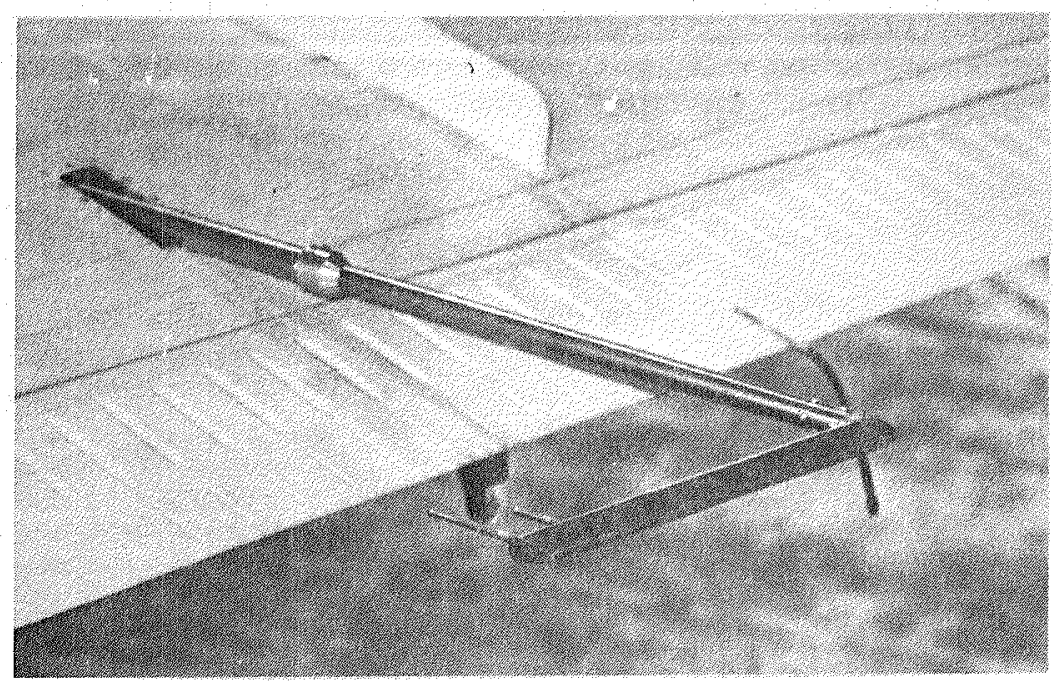

Figure 3. - Wake survey probe on right wing.

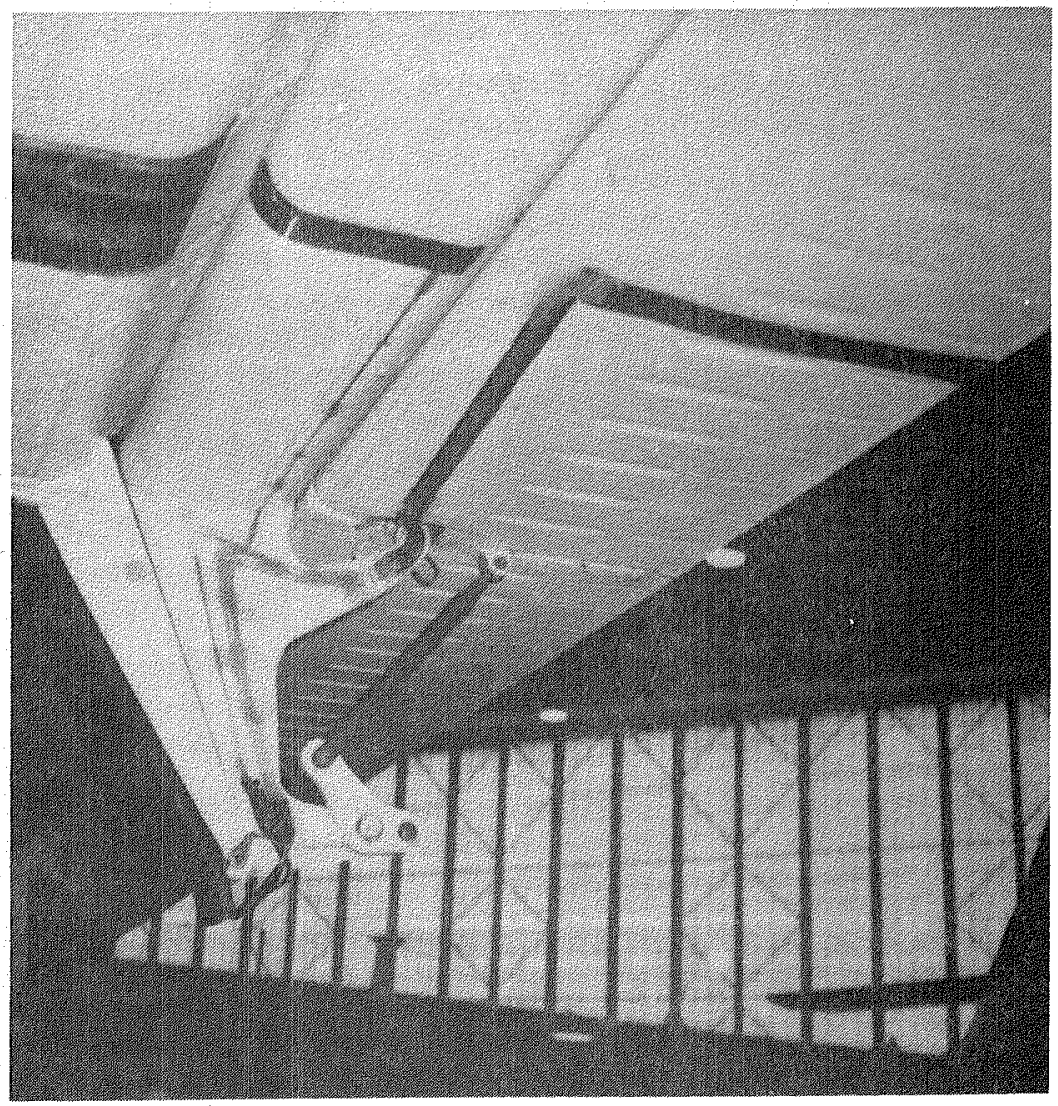

Figure 4. - Surface pressure belt on left wing. 


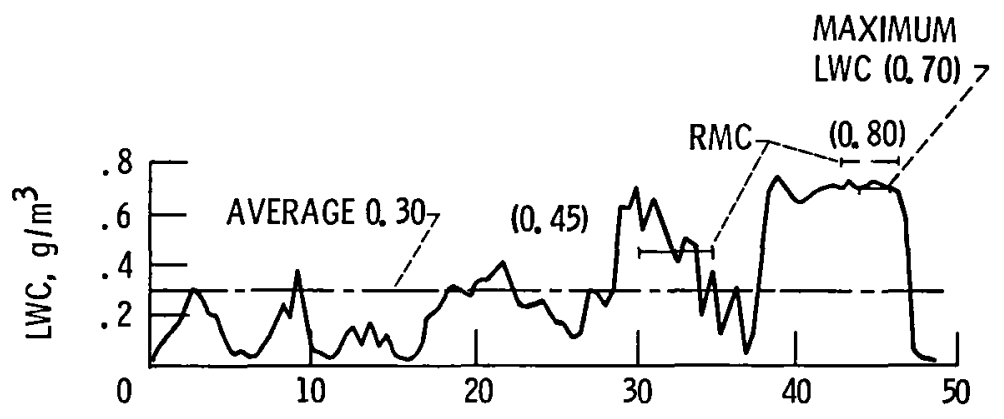

(a) FLT 84-19.

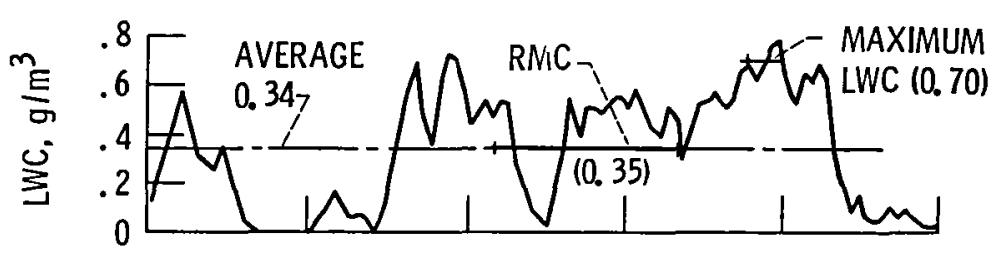

(b) FLT 84-27.

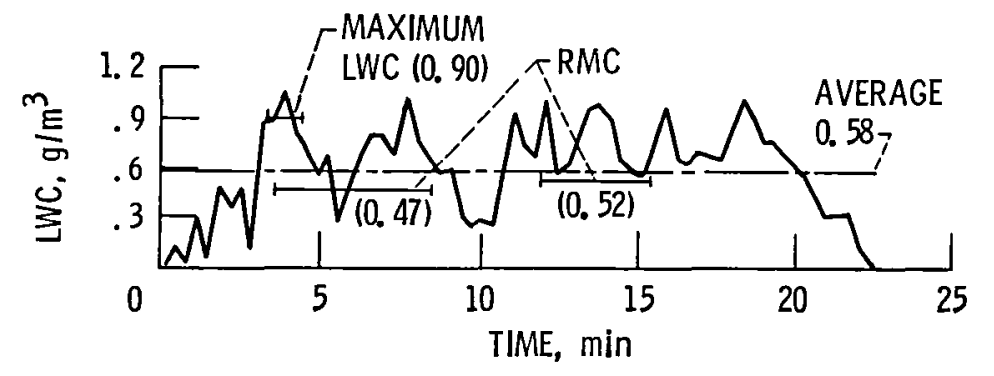

(c) FLT $84-34$

Figure 5. - Variation of liquid water content (LWC) with tıme for three IcIng encounters. LWC measured continuously by Johnson and William's IIquid water content meter and intermittently by rotating multıcylınders. 


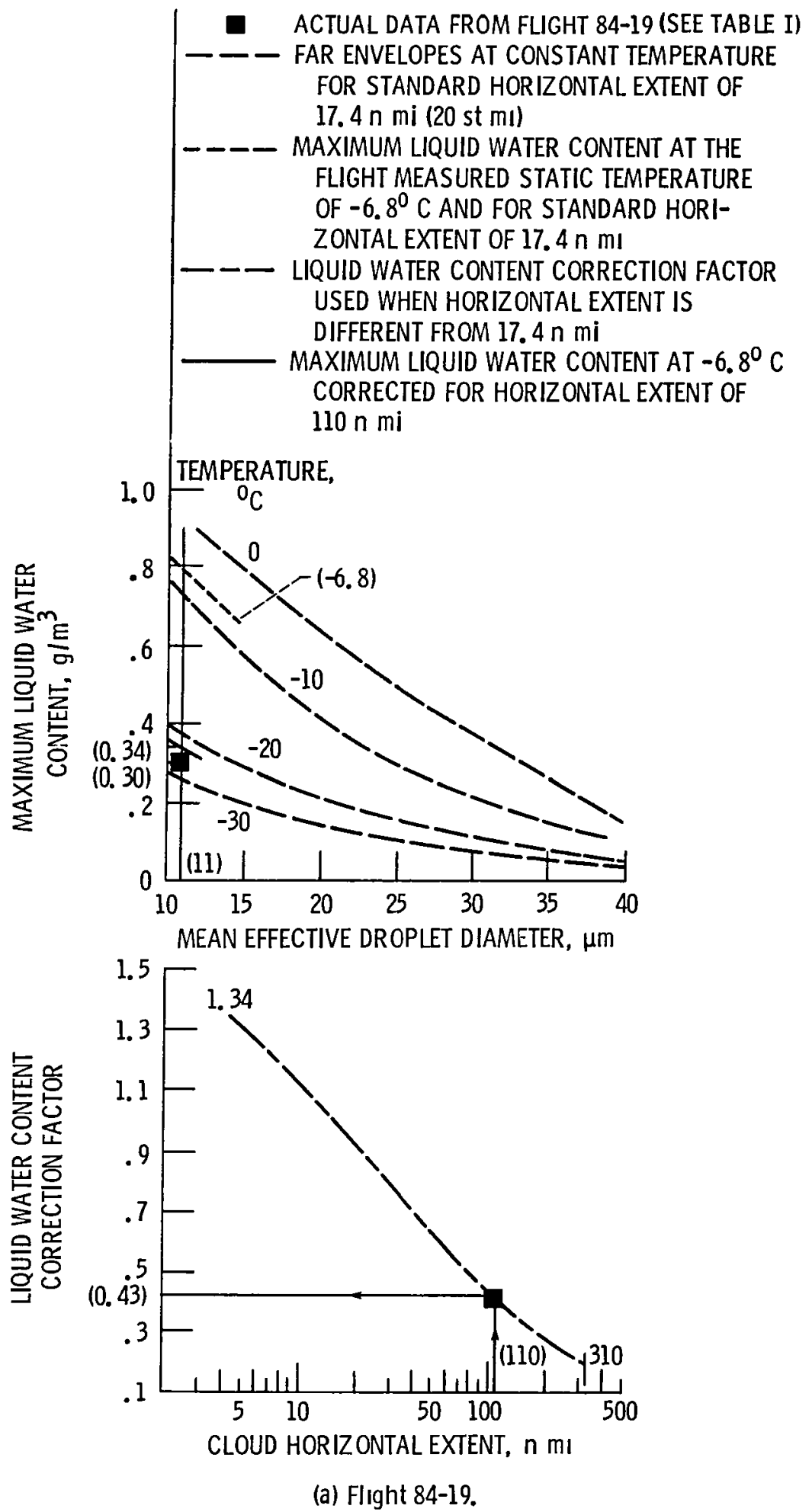

Figure 6. - Icing encounters superimposed on FAR appendix $\mathrm{C}$ of part 25 continuous maximum (stratiform clouds). 


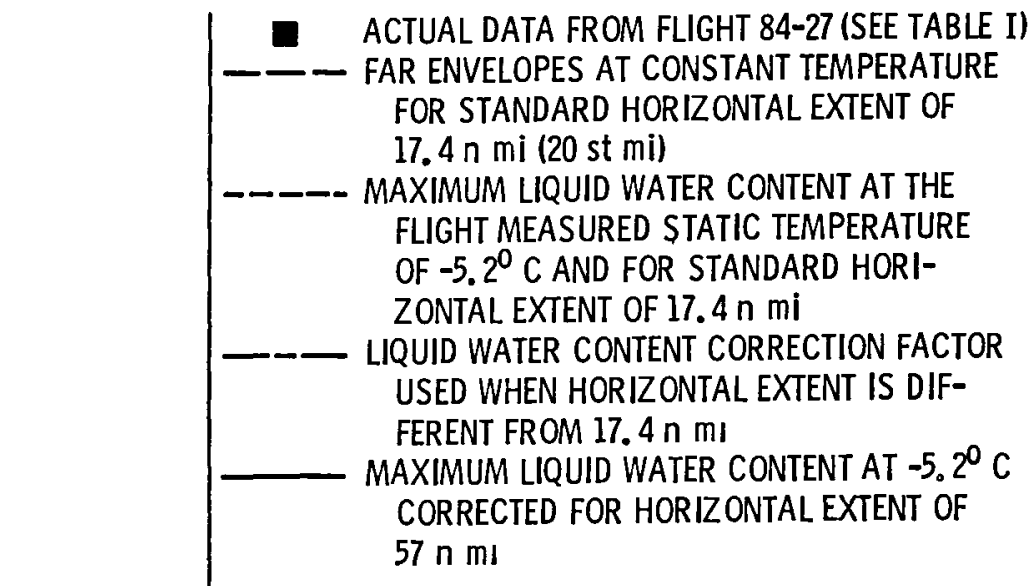

TEMPERATURE,
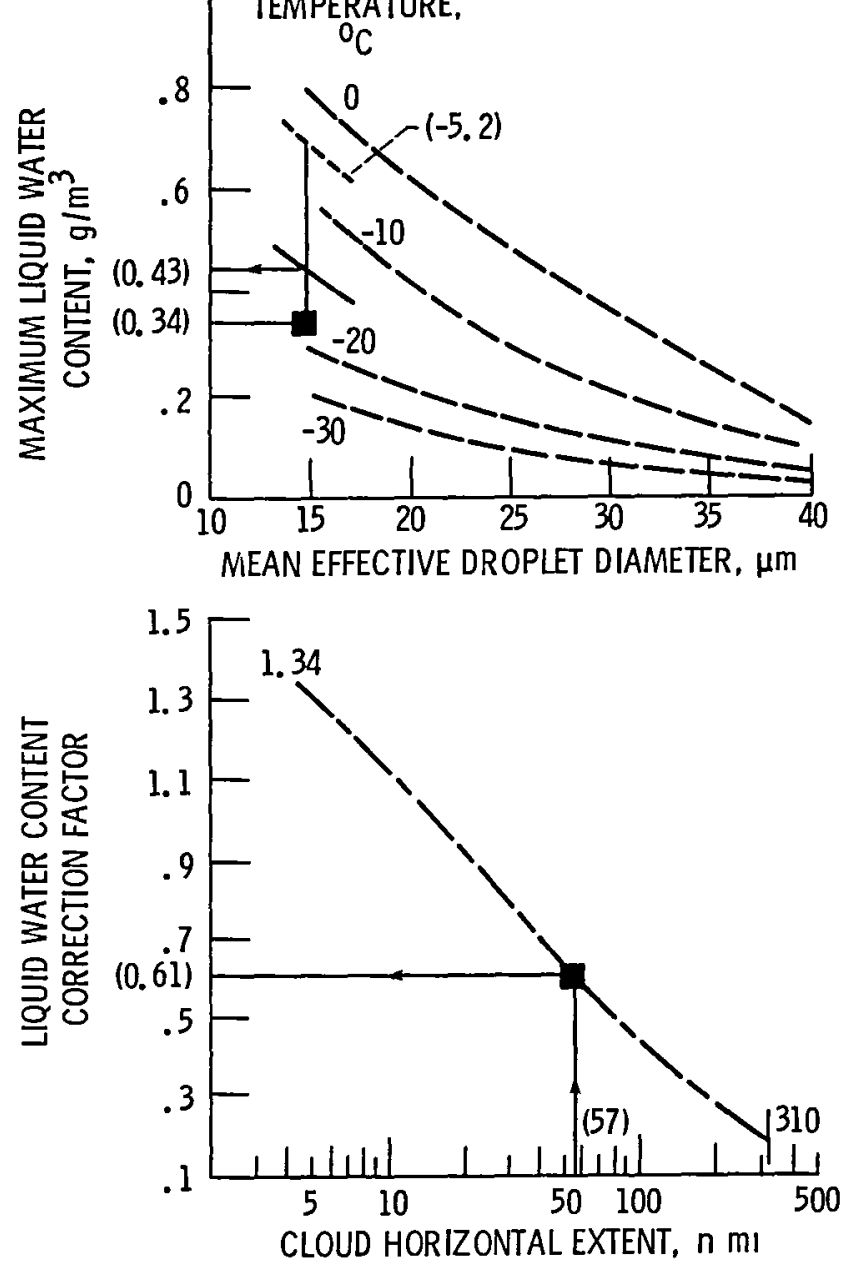

(b) Flight 84-27.

Figure 6. - Contınued. 


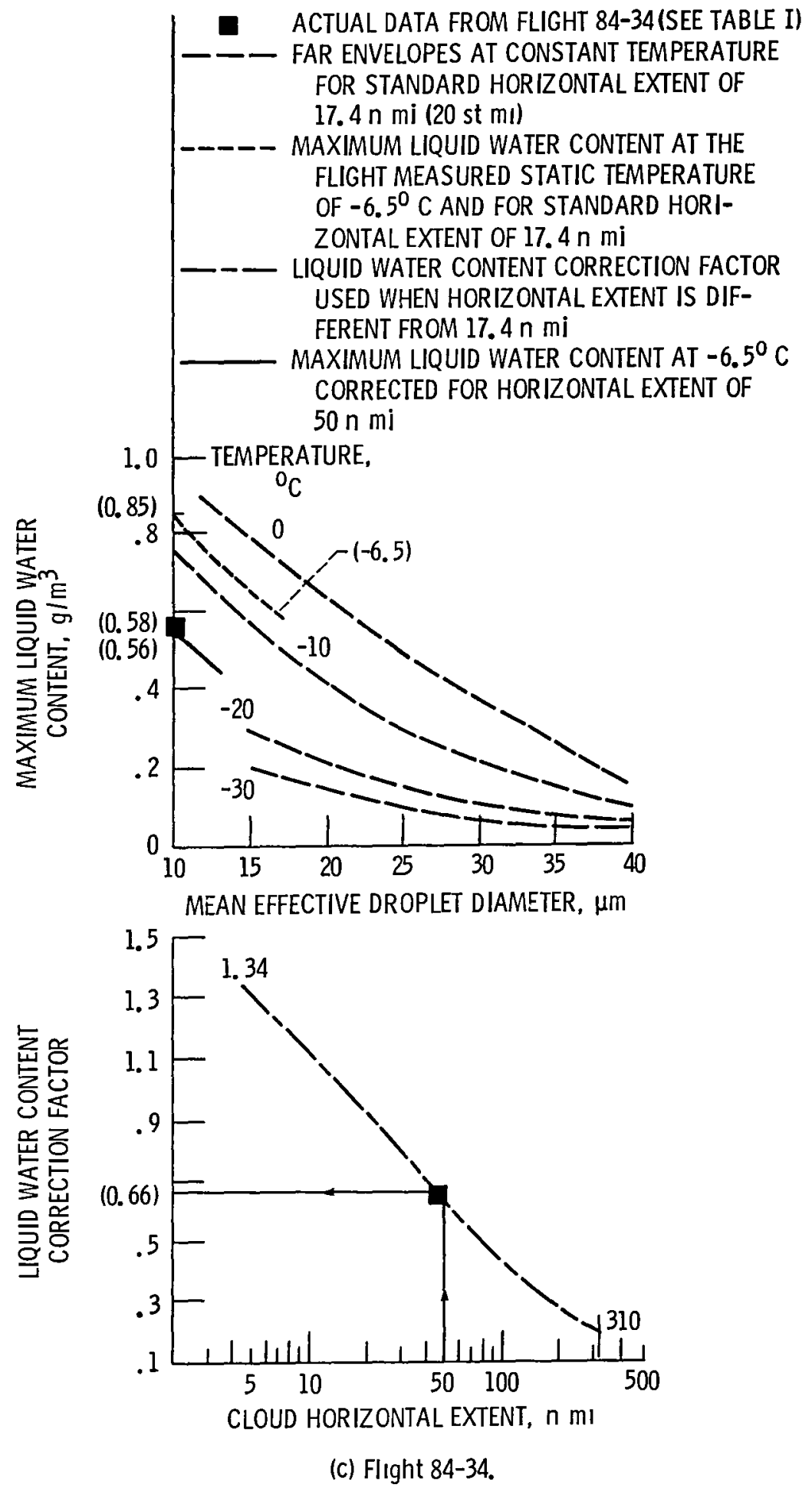

Figure 6. - Concluded. 


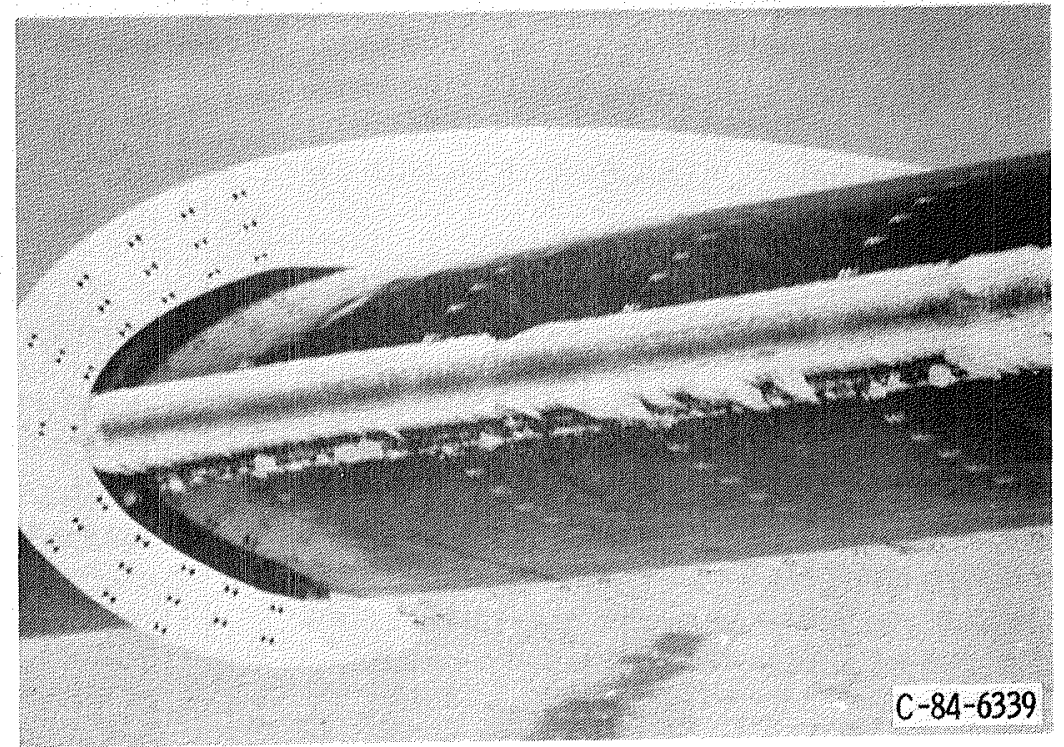

(a) Wing leading edge ice formation.

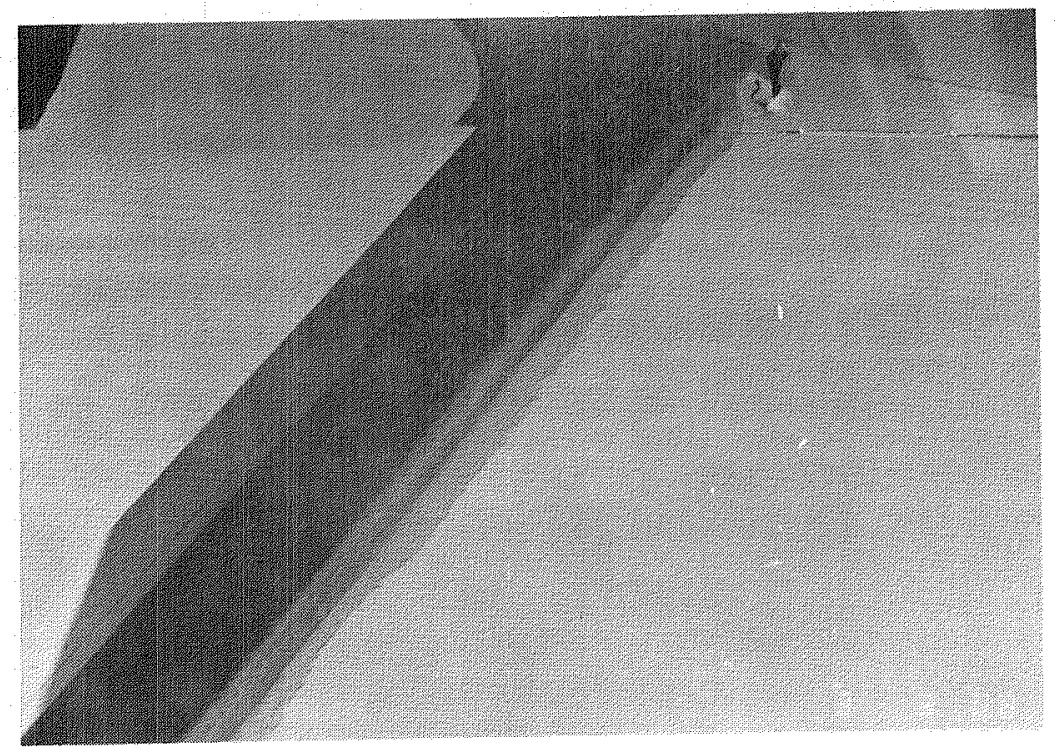

(b) Ice for mation on wing strut.

Figure 7. - Ice accretions on aircraft at time of aerodynamic measurements for flight 84-19. 


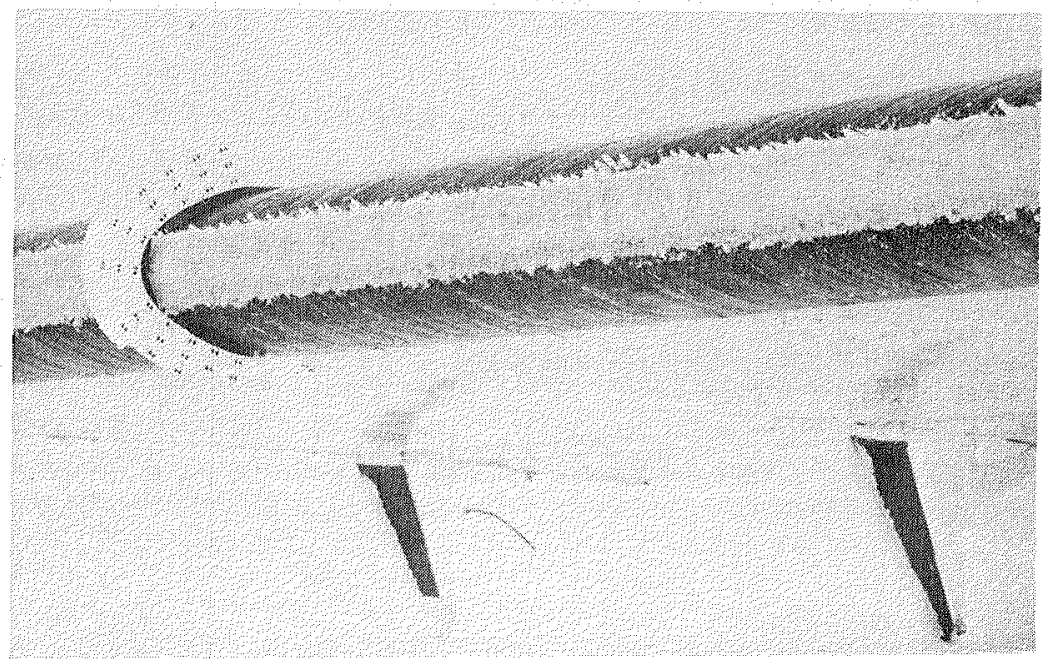

(a) Wing leading edge ice for mation.

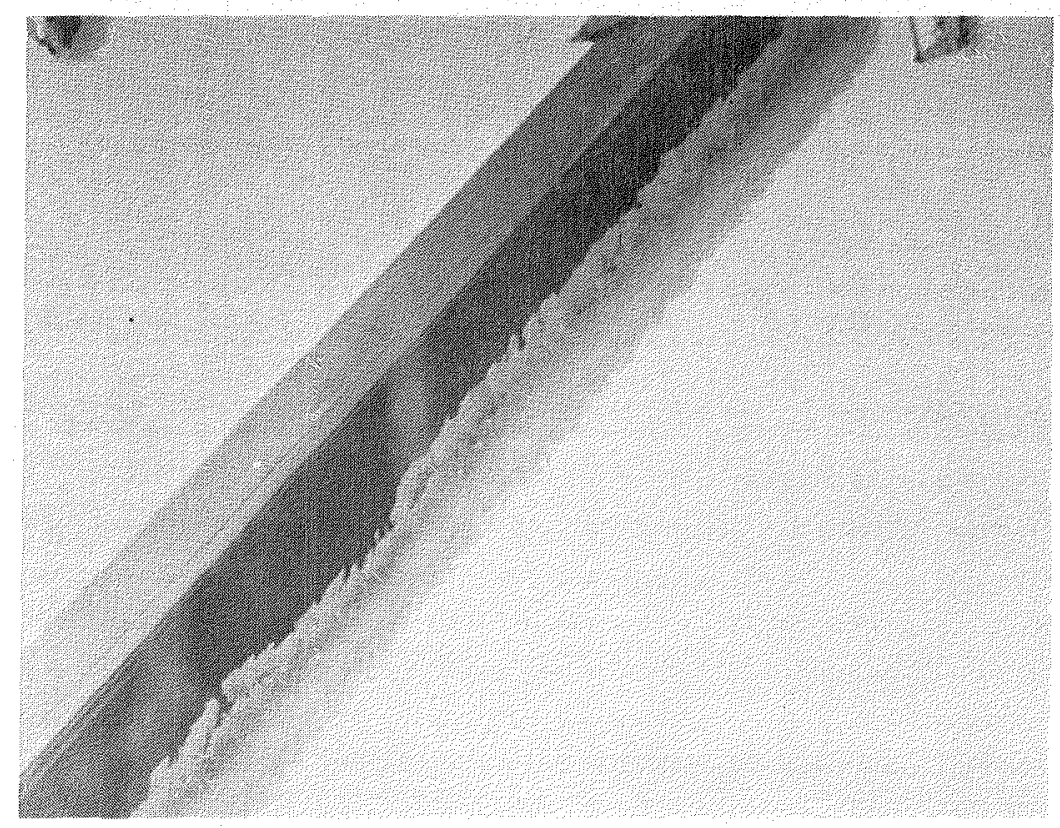

(b) Ice for mation on wing strut.

Figure 8. - Ice accretions on aircraft at time of aerodynamic measurements for flight 84-27. 


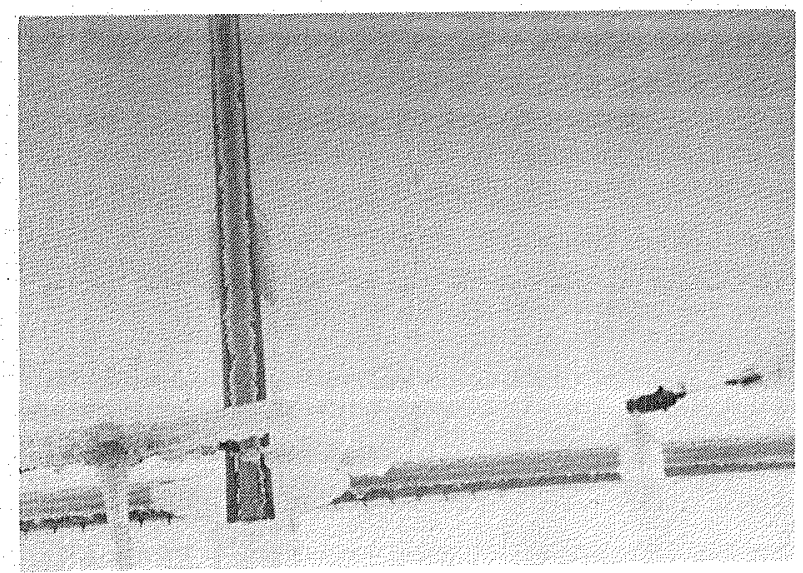

(c) Ice formation on empennage.

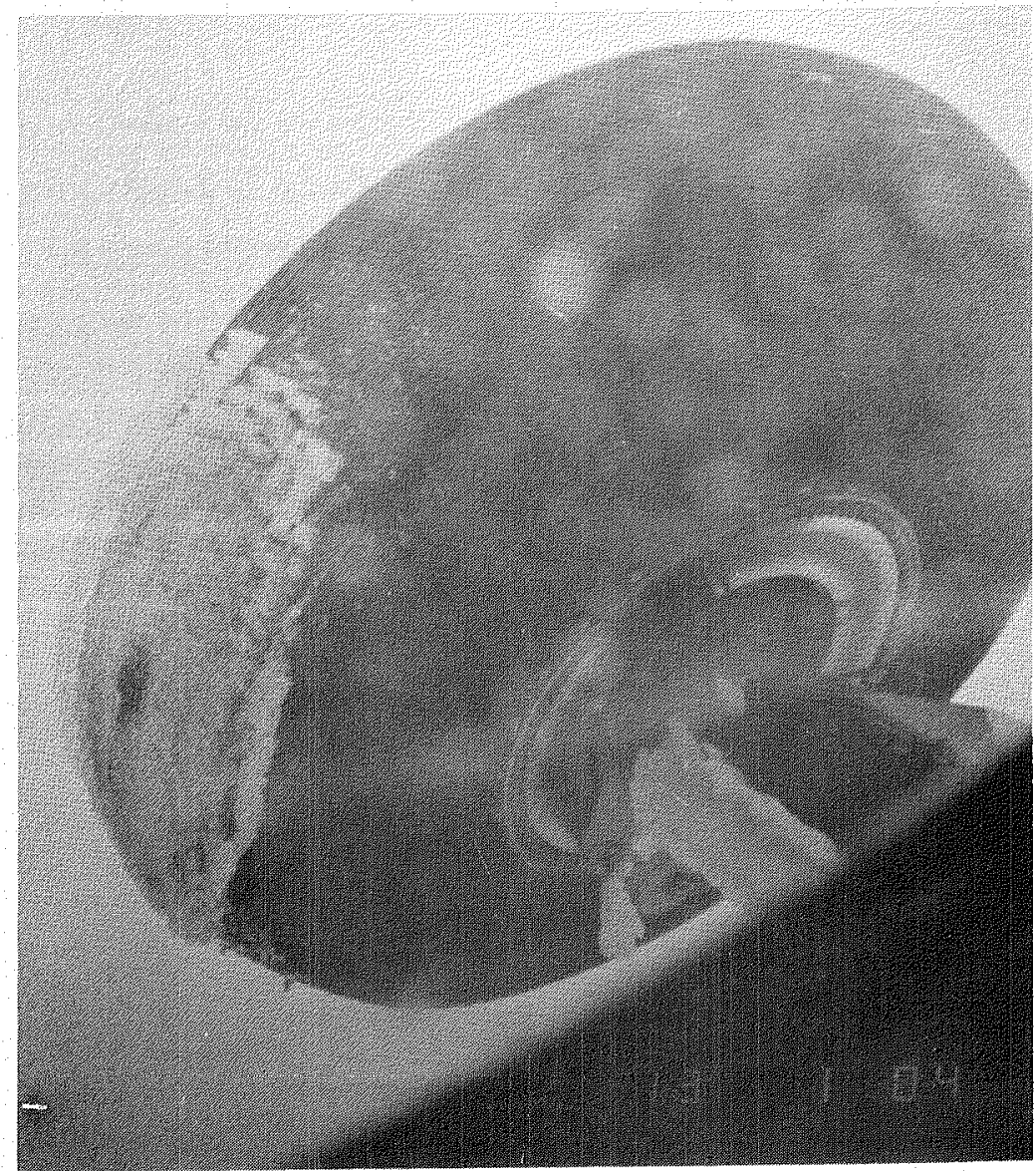

(d) Ice for mation on wheel and landing gear strut.

Figure 8. - Concluded. 


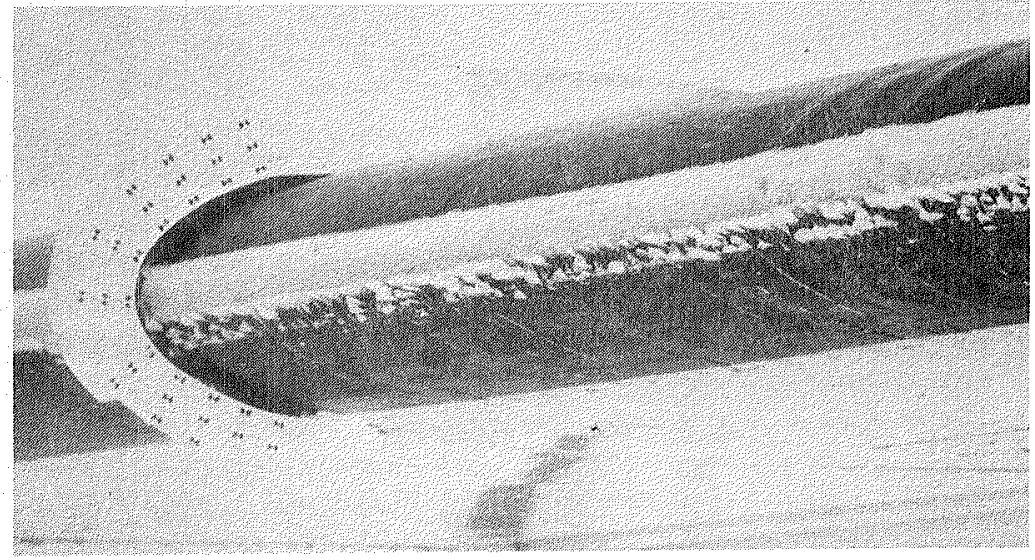

(a) Wing leading edge ice formation.

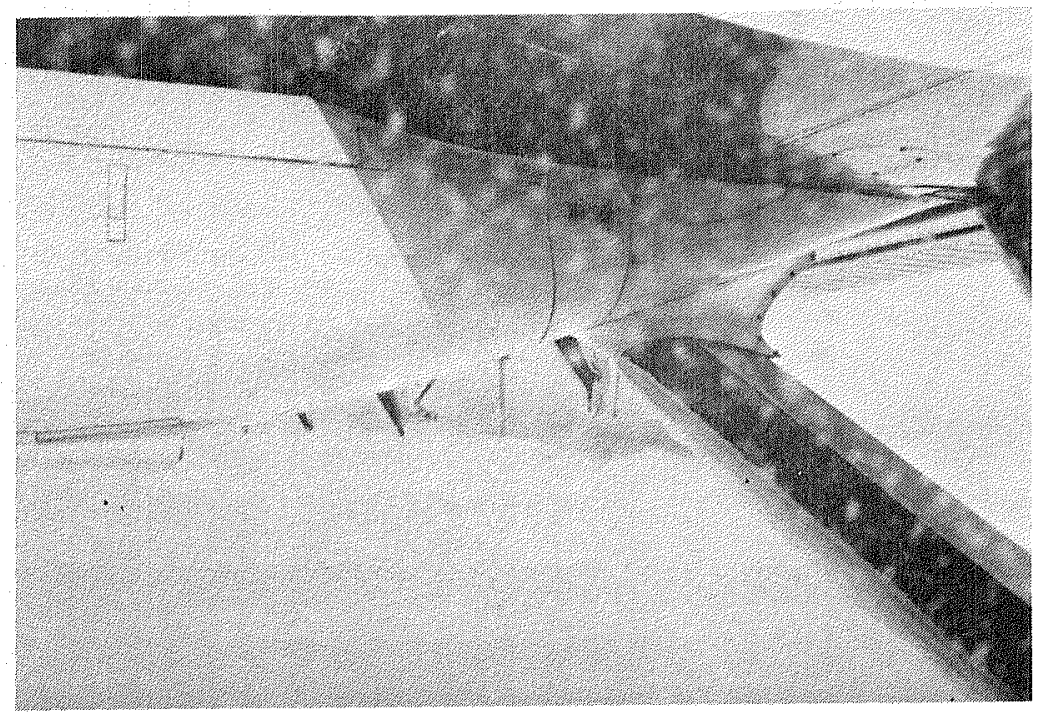

(b) Ice for mation on wing strut.

Figure 9. - Ice accretions on aircraft at time of aerodynamic measurements for flight 84-34. 


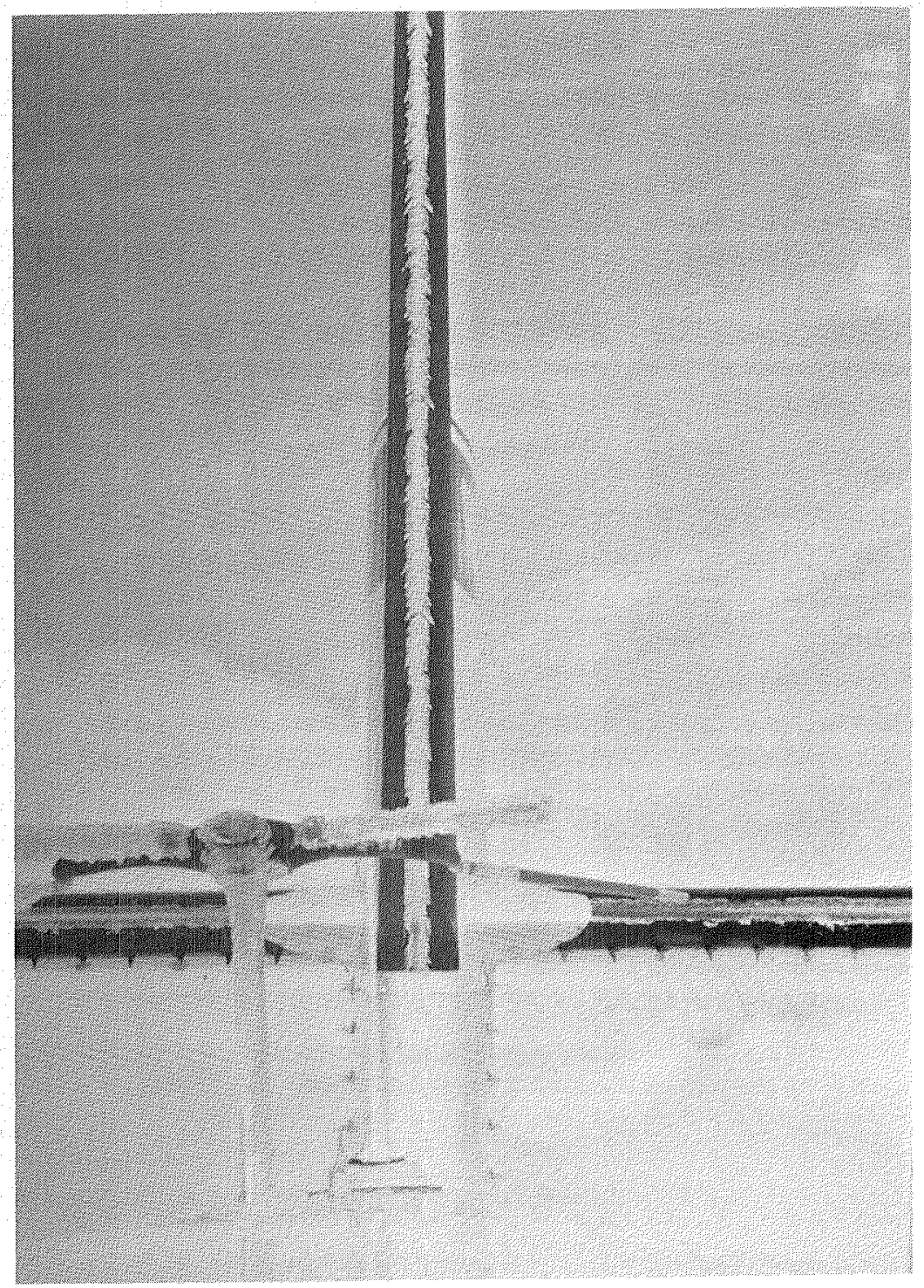

(c) Ice for mation on empennage.

Figure 9. - Concluded. 


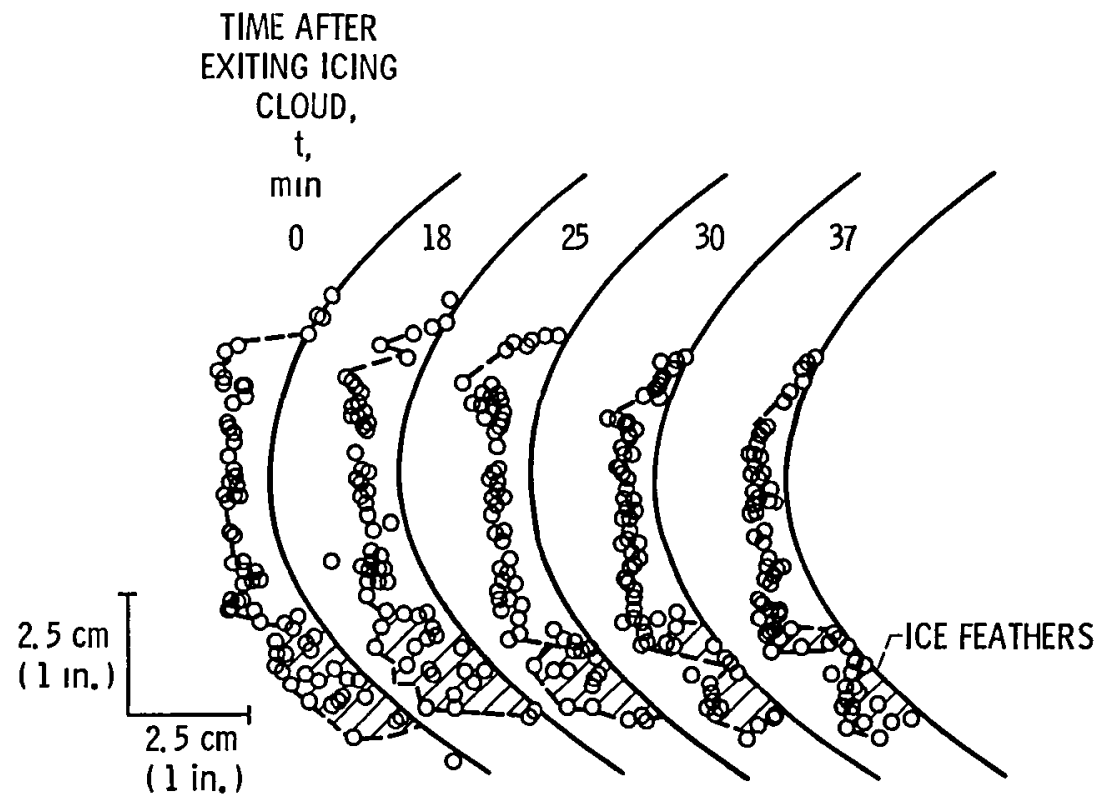

Figure 10. - Stereophotography results showing variation in composite ice profiles with tıme (after exitıng the icıng cloud). 

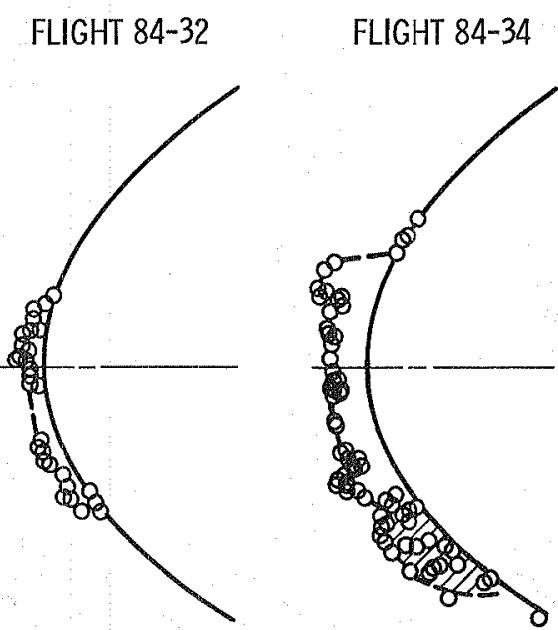

FLIGHT $84-29$
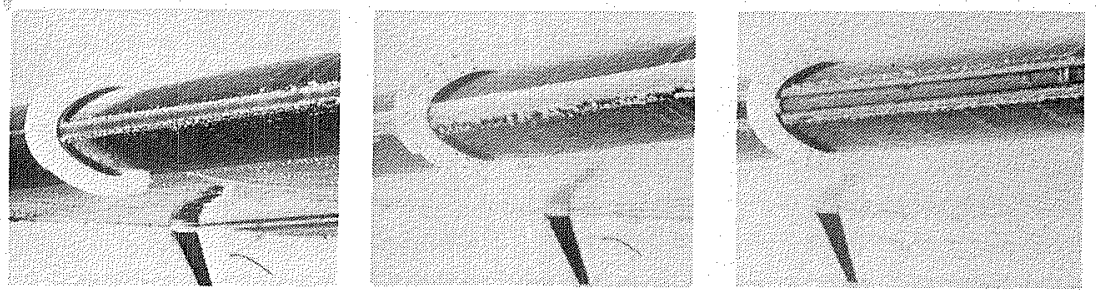

MVD (SOOT SIDE), $\mu \mathrm{m}$

MED (RMC), $\mu \mathrm{m}$

6

LANGMUIR DISTRIBUTION

E (SLIDES)

10.1

14.6

MAXIMUM DIAMETER, $\mu \mathrm{m}$

16 (SLIDES)

E (RMC)

$E(R M C)$

(5\% vol. ABOVE THIS)

LWC, $g / \mathrm{m}^{3}$

STATIC TEMPERATURE, ${ }^{\circ} \mathrm{C}$

0.23

28 (RMC)

$40(\mathrm{RMC})$

TRUE AIRSPEED, KTAS

PRESSURE ALTITUDE, $\mathrm{ft}$

ICING DURATION, min

$-4$

0.58

0.15

141

$-6$

$-7$

8200

137

145

37

5600

7600

22

49

Figure 11. - Correlation of ice accretion extent on wing surface with cloud droplet size (larger drop sizes produce greater ice coverage of wing surface). 


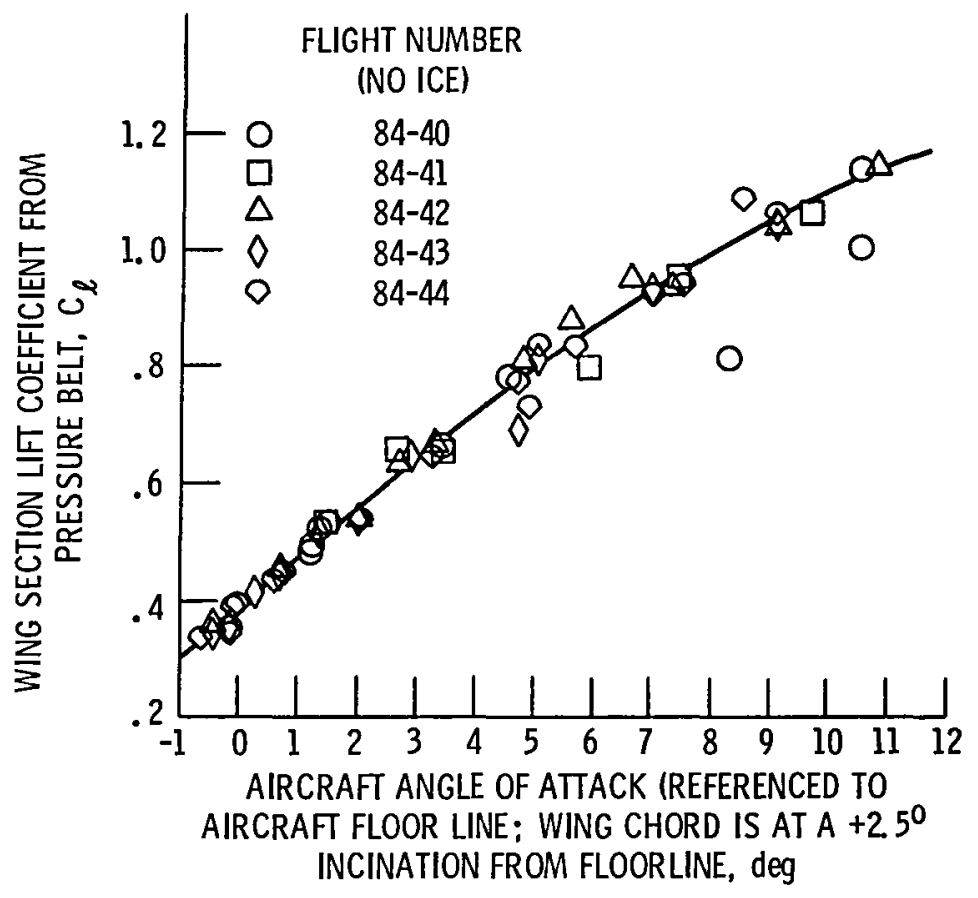

Figure 12. - Uniced lift curve for wing section. $\delta_{F}=0^{0}$.

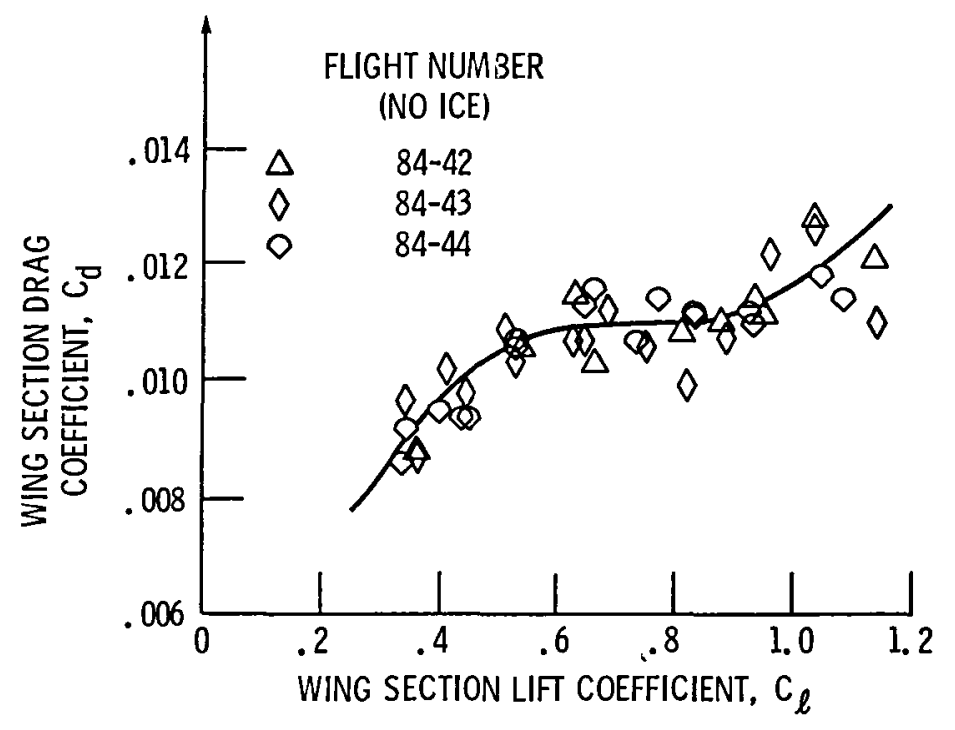

Figure 13. - Uniced drag polar for wing section. $\delta_{\mathrm{F}}=0^{0}$. 


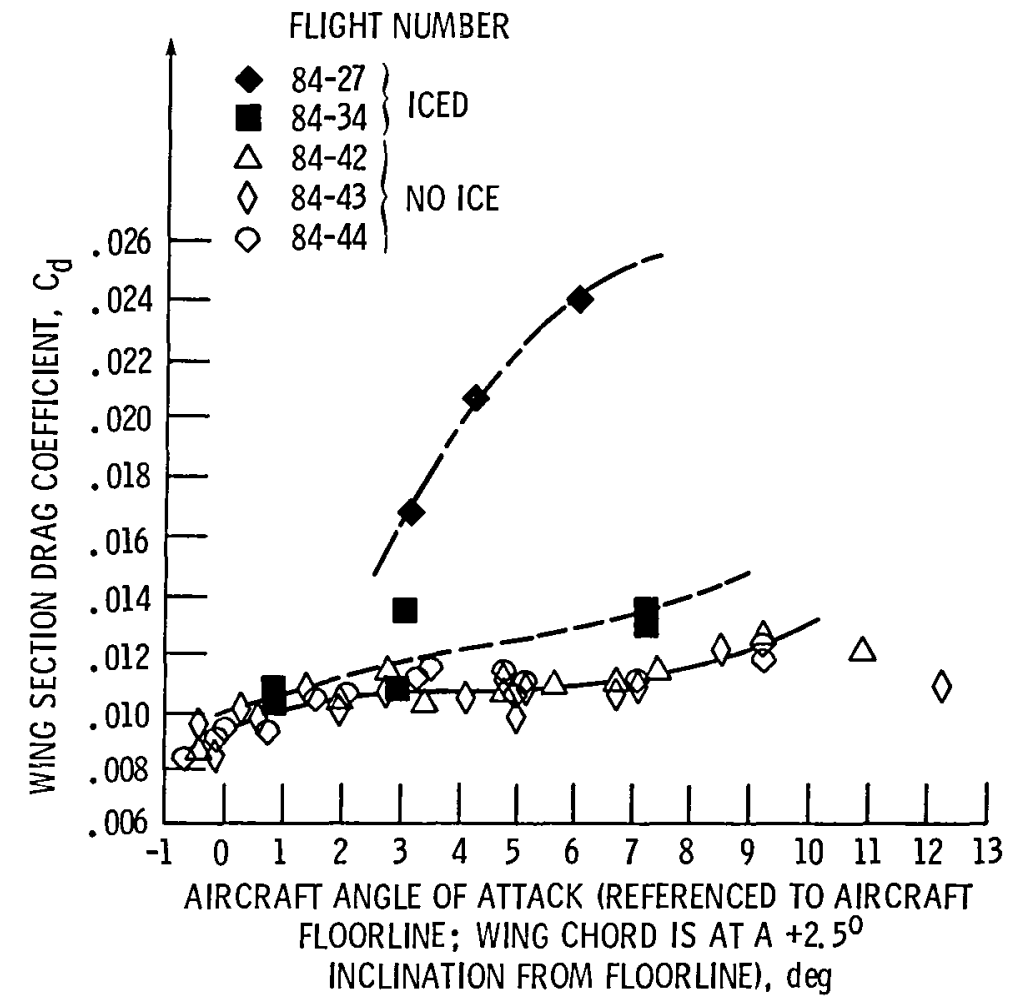

Figure 14. - Comparison of wing section drag coefficient as a function of aircraft angle of attack for the iced and uniced wing. $\delta_{F}=0^{\circ}$. 


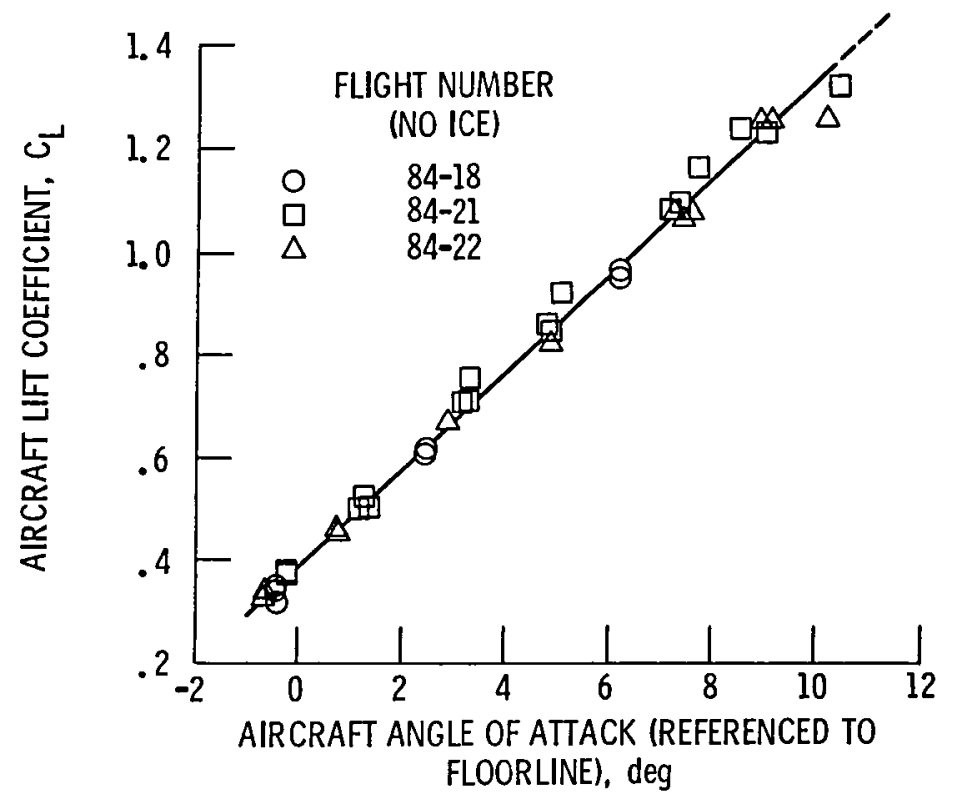

(a) Lift curve.

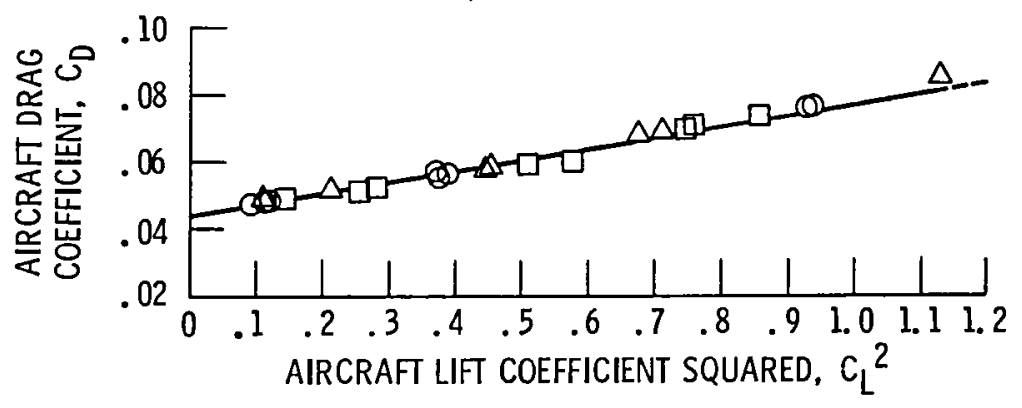

(b) Drag polar.

Figure 15. - Lift curve and drag polar for uniced Icing research aircraft (baselıne). $\delta_{F}=0^{0}$. 


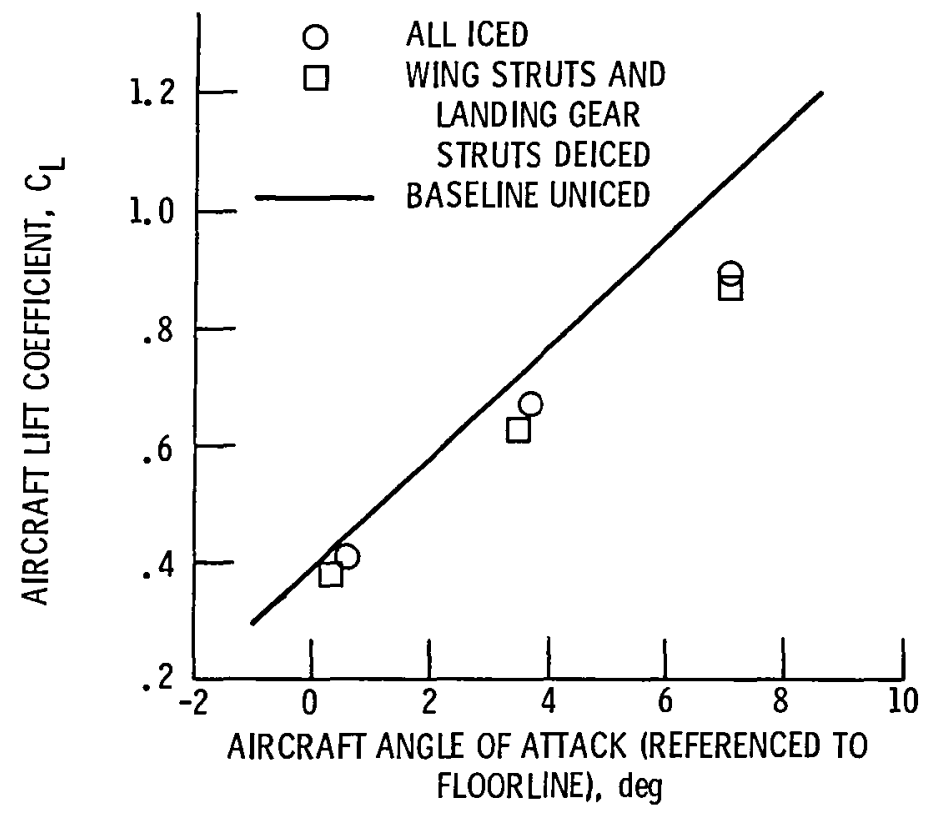

(a) Lift curve.

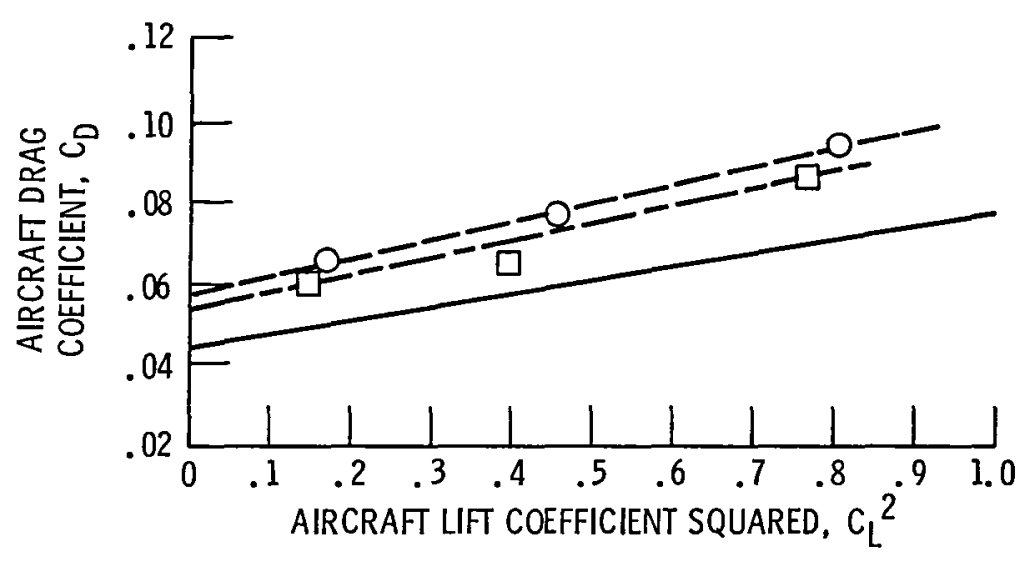

(b) Drag polar.

Figure 16. - Change in aircraft lift curve and drag polar due to ice for flight 84-19. $\delta_{F}=0^{0}$ 。 


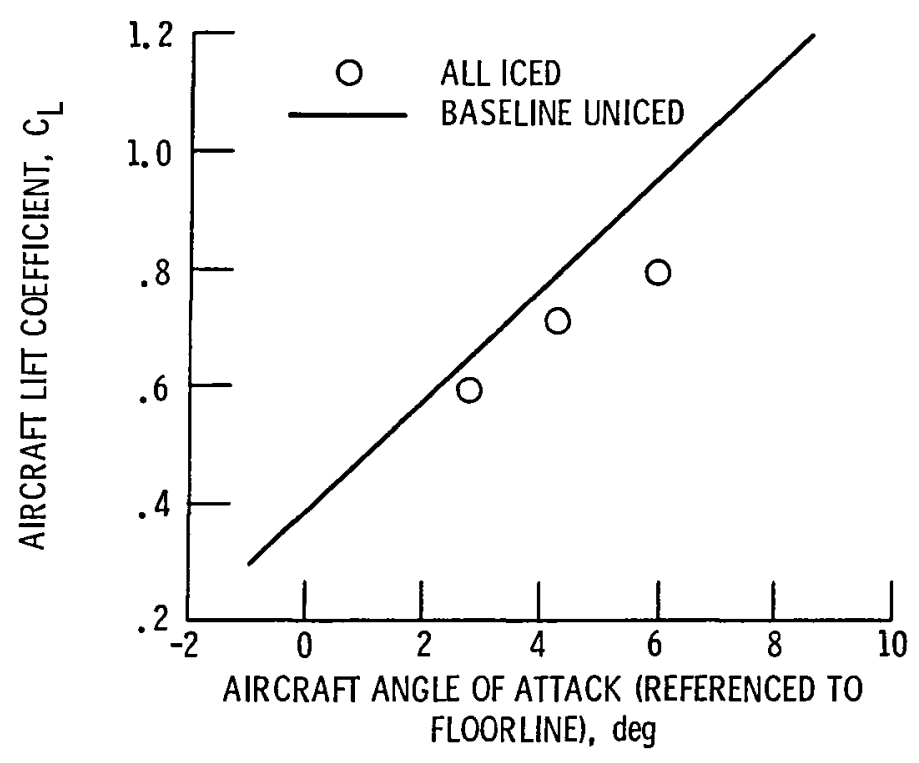

(a) Lift curve.

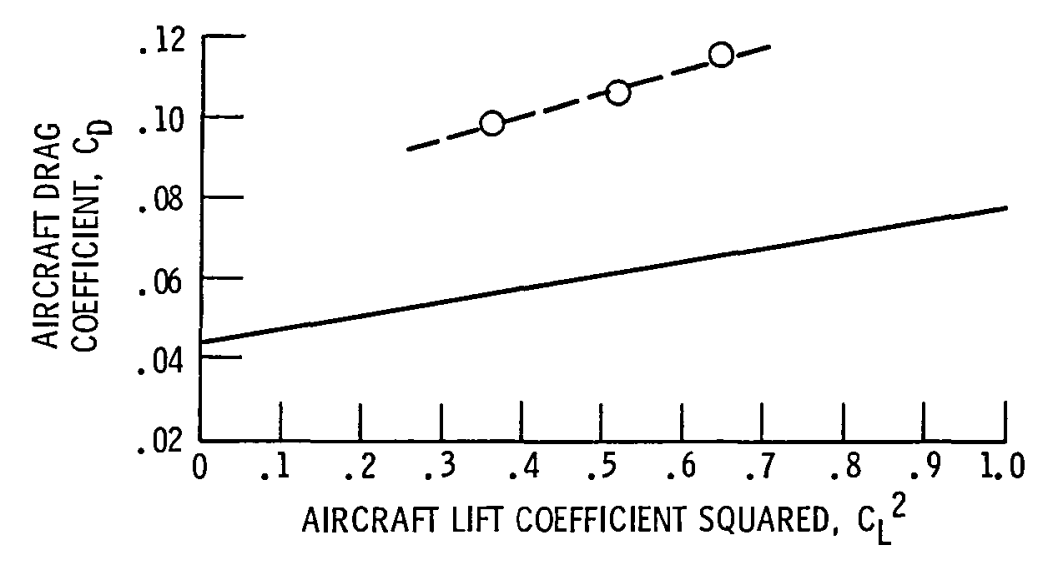

(b) Drag polar.

Figure 17. - Change in aircraft lift curve and drag polar due to ice for flight 84-27. $\delta_{F}=0^{0}$. 


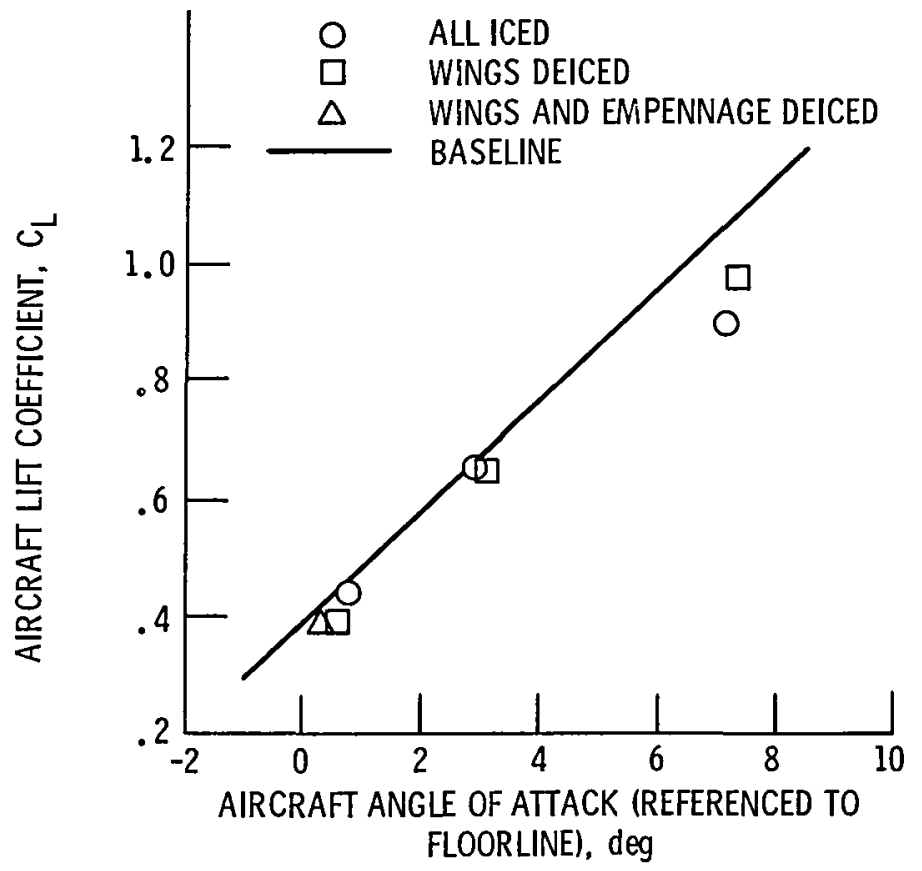

(a) Lift curve.

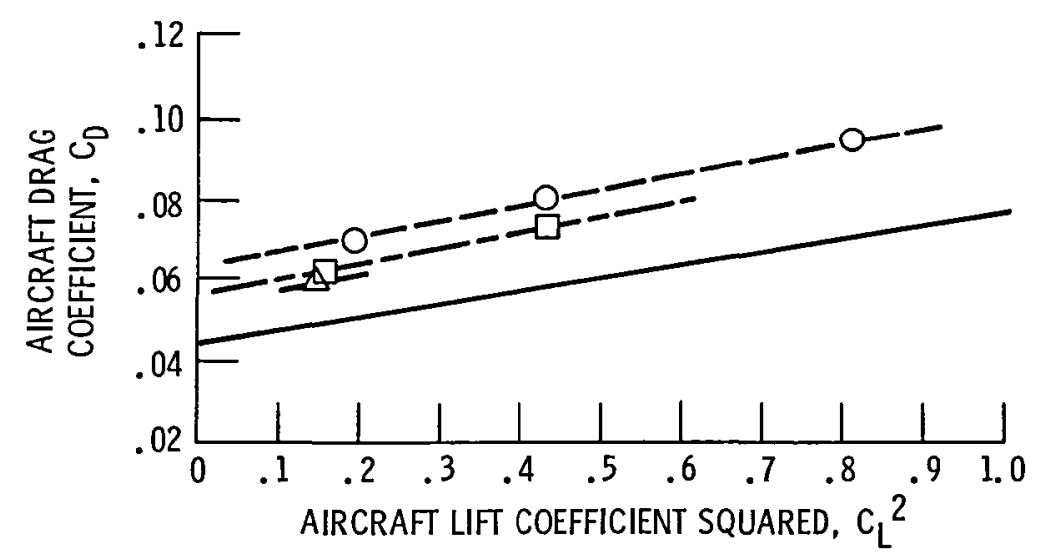

(b) Drag polar.

Figure 18. - Change in aircraft lift curve and drag polar due to ice for flight $84-34 . \quad \delta_{F}=0^{0}$. 


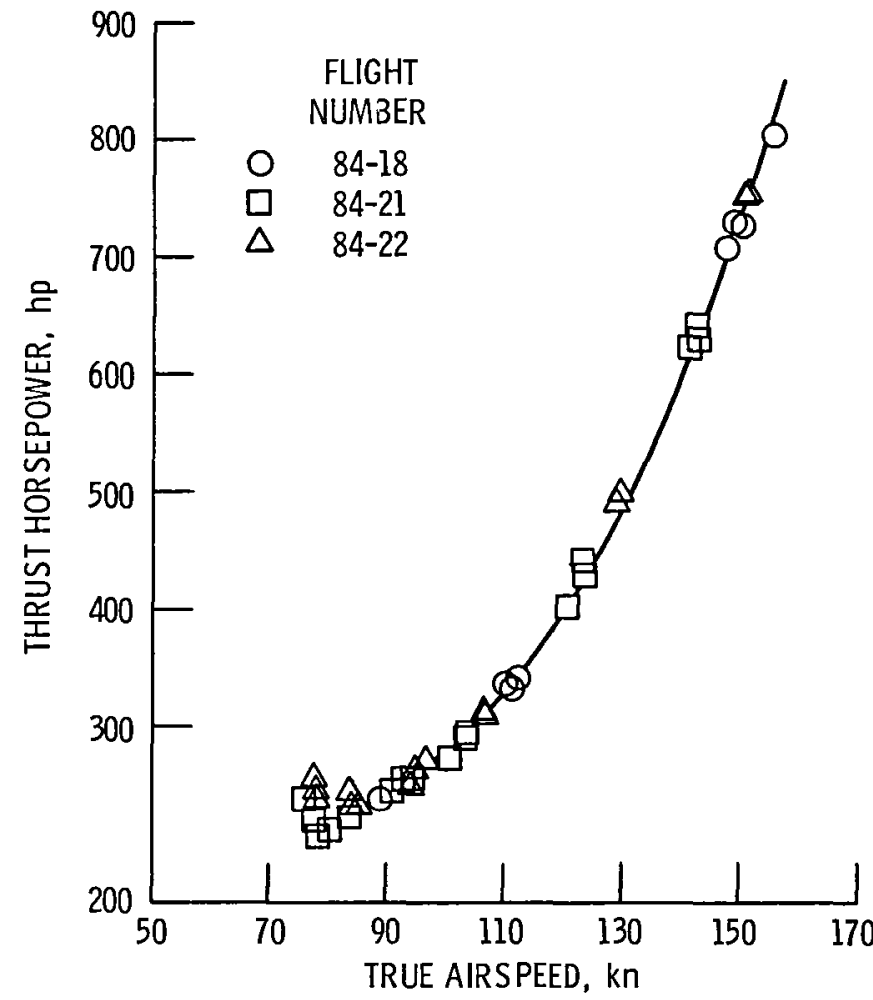

(a) Thrust horsepower required as a function of velocity for the uniced aircraft. Flight test data corrected to standard day, sea level, and standard weight conditions (11 $000 \mathrm{lb})$ (baselıne).

Figure 19. - Flight 84-27, effect of glaze Icıng on thrust horsepower required relative to calculated one engine thrust horsepower avaılable. $\delta_{F}=0^{0}$. 


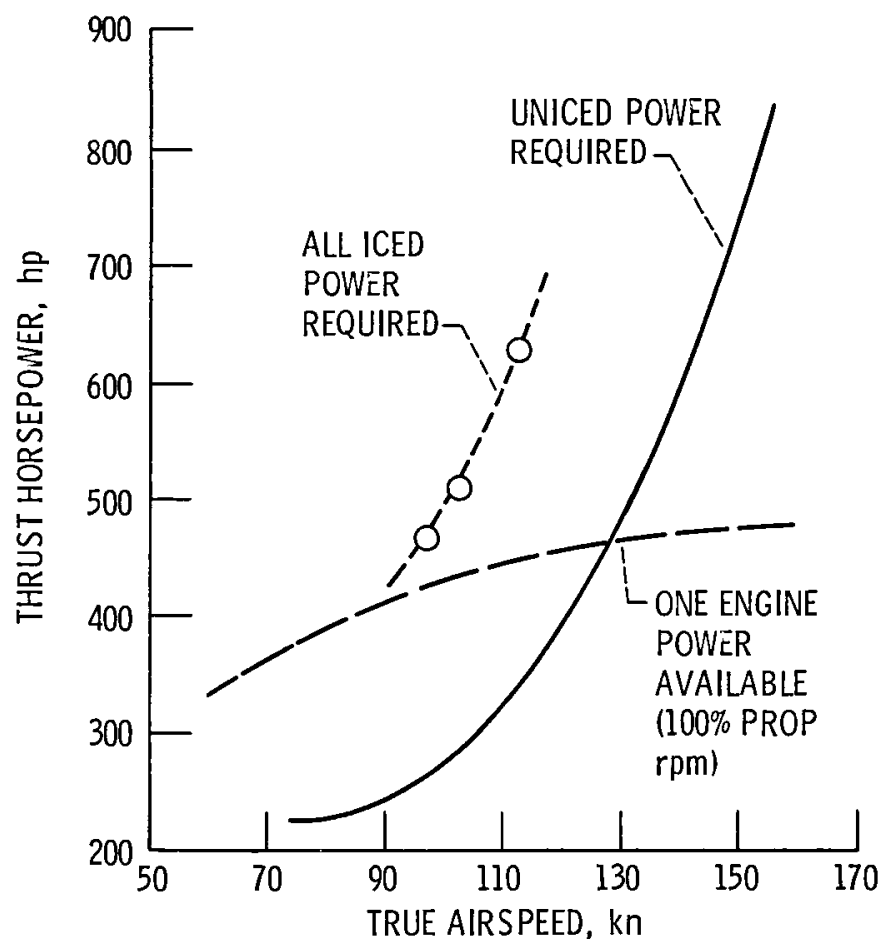

(b) Flıght test data corrected to standard day, sea level, and standard weight conditions

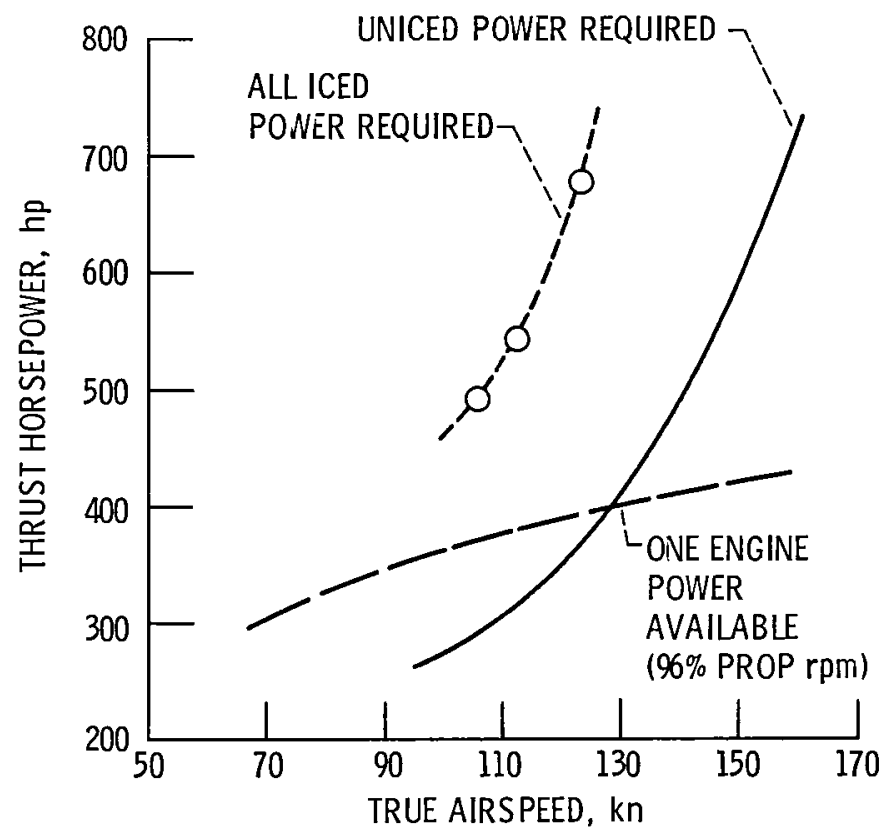

(c) Test conditions at $7600 \mathrm{ft}$, flight test data corrected to standard weight only.

Figure 19. - Concluded. 


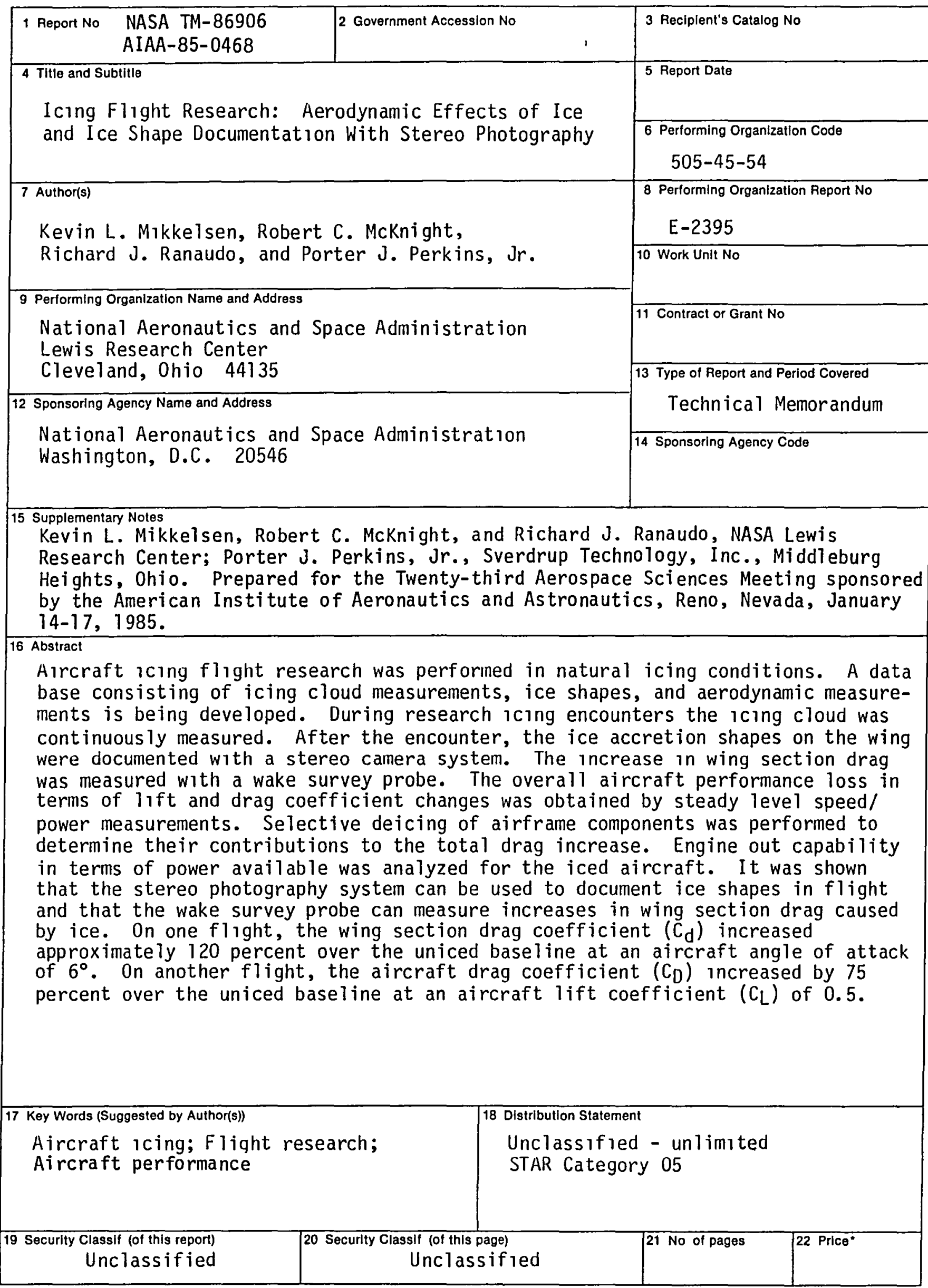

"For sale by the National Technical Information Service, Springfıeld, Virgınıa 22161 
End of Document 